\title{
Warming-driven mass extinction in the Early Toarcian (Early Jurassic) of northern and central Spain. Correlation with other time-equivalent European sections
}

\author{
Juan J. Gómez ${ }^{\mathrm{a}} *$, Antonio Goy ${ }^{\mathrm{b}}$ \\ ${ }^{a}$ Dpto. de Estratigrafía, Facultad de Ciencias Geológicas (UCM) and Instituto de Geociencias (CSIC-UCM), 28040 Madrid, Spain \\ ${ }^{\mathrm{b}}$ Dpto. de Paleontología, Facultad de Ciencias Geológicas (UCM) and Instituto de Geociencias (CSIC-UCM), 28040 Madrid, Spain
}

\begin{abstract}

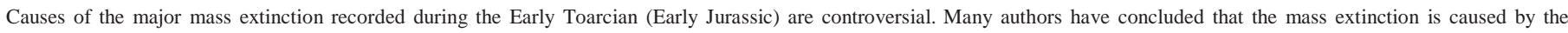

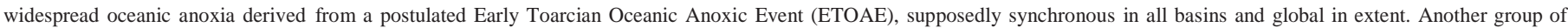

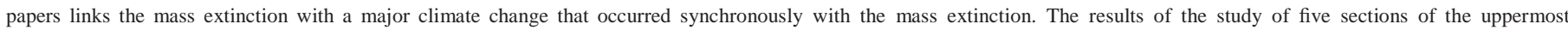

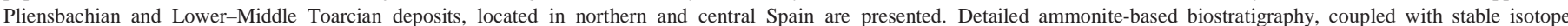

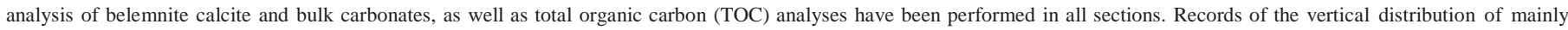
benthic fossils have been compiled in four of the studied sections. Results obtained in the Spanish outcrops have been compared and correlated with other European sections.

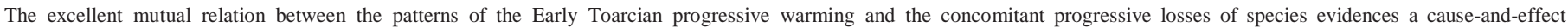

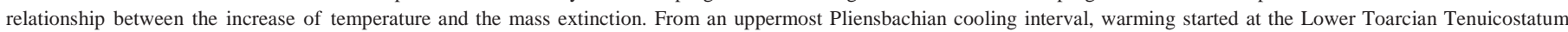

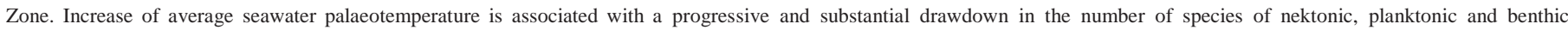

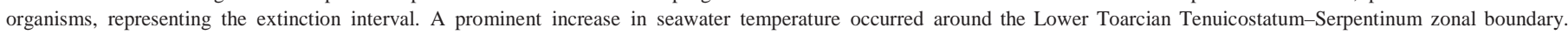

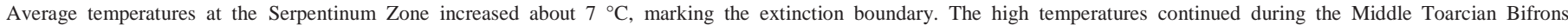

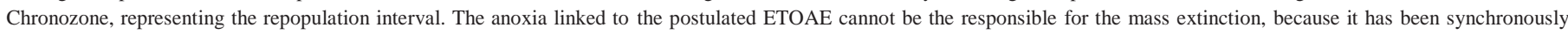

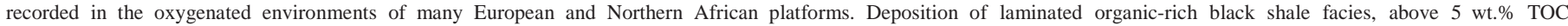

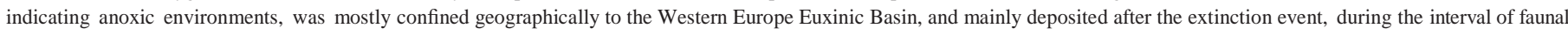
recovery.
\end{abstract}

Keywords: Climatechange, Mass extinction, Jurassic, Oxygen isotope, Recovery

\section{Introduction}

The occurrence of a major mass extinction during the Early Toarcian (Early Jurassic, 183-181.2 Ma; Ogg, 2004) has been reported by many authors in western Europe (e.g. Hallam, 1986, 1987, 1996; Arias et al., 1992; Little and Benton, 1995; Harries and Little, 1999; Pálfy and Smith, 2000; Cecca and Macchioni, 2004; Gómez et al., 2008; Bilotta et al., 2009; Dera et al., 2010), in South America (Aberhan and Fürsich, 1997; Aberhan and Baumiller, 2003), in Siberia (Nikitenko, 2008) and in northern Africa (Bassoullet et al., 1991). Timing of the Early Toarcian mass extinction can be precisely constrained on the basis of ammonite biostratigraphy. Numerous research works, mainly

\footnotetext{
* Corresponding author. Tel.: +34913944783; fax: +34913944808.

E-mail addresses: jgomez@geo.ucm.es(J.J.Gómez), angoy@geo.ucm.es (A. Goy).
}

performed in the European sections, demonstrated that the extinction interval develops through the uppermost Pliesbachian Spinatum Zone and the lowermost Toarcian Tenuicostatum Zone, and that the extinction boundary is located around the limit between the Lower Toarcian Tenuicostatum and Serpentinum zones or their equivalents in other bioprovinces (e.g. Almeras and Fauré, 1990; Bassoullet et al., 1991; Arias et al., 1992; Bassoullet and Baudin, 1994; Nocchi and Bartolini, 1994; Little and Benton, 1995; Hallam, 1996; Harries and Little, 1999; Joral and Goy, 2000; Macchioni, 2002; Macchioni and Cecca, 2002; Vörös, 2002; Cecca and Macchioni, 2004; Gahr, 2005; Ruban and Tyszka, 2005; Wignall et al., 2005; Gómez et al., 2008; Bilotta et al., 2009; Dera et al., 2010; Gómez and Arias, 2010; Gómez and Goy, 2010; García Joral et al., 2011).

However, there is not a general agreement on the causes of the Early Toarcian mass extinction. The debate is mainly centered around two different hypotheses. Many authors have concluded that the mass 

extinction is caused by the widespread anoxia in the oceans as a result of a supposed major, synchronous and global in extent, Oceanic Anoxic Event (e.g. Jenkyns, 1988; Bassoullet and Baudin, 1994; Nikitenko and Shurygin, 1994; Little and Benton, 1995; Harries and Little, 1999; Hesselbo et al., 2000; Hylton and Hart, 2000; Pálfy and Smith, 2000; Guex et al., 2001; Bucefalo Palliani et al., 2002; Macchioni, 2002; Vörös, 2002; Aberhan and Baumiller, 2003; Mattioli et al., 2004; Tremolada et al., 2005; Wignall et al., 2006; Mailliot et al., 2006, 2009; Pearce et al., 2006; Bilotta et al., 2009; Mattioli et al., 2009; Hart et al., 2010). This anoxic event is marked in the stratigraphical record by the presence of laminated organic-rich black shale facies (Jenkyns, 1988), which implies the deposition of rocks containing more than 5 wt.\% of total organic carbon (TOC) (Bates and Jackson, 1987; Kearey, 2001; McArthur et al., 2008). Another group of papers, links the mass extinction with a major climate change that conducted to an important and rapid warming (Kemp et al., 2006) that occurred synchronously with the mass extinction (Gómez et al., 2008; Gómez and Arias, 2010; Gómez and Goy, 2010; García Joral et al., 2011).

The occurrence of important variations in the $\delta^{18} \mathrm{O}$ values and hence in the palaeotemperature of the oceans during the latest Pliensbachian-Early Toarcian has been documented by many authors in several parts of Western Europe (Chandler et al., 1992; Sælen et al., 1996; McArthur et al., 2000; Röhl et al., 2001; Schmid-Röhl et al., 2002; Jenkyns, 2003; Rosales et al., 2004; Gómez et al., 2008; Metodiev and Koleva-Rekalova, 2008; Dera et al., 2009; Gómez and Arias, 2010; García Joral et al., 2011; Suan et al., 2008, 2010; Dera et al., 2011), and have also been reported in the North Siberia and the Arctic Region (Zakharov et al., 2006; Nikitenko, 2008).

Numerous unknowns and many contradictory hypotheses about the causes of the Early Toarcian mass extinction and its possible links with anoxia or with climate change are still waiting to be clarified. To provide additional data for testing of the different hypotheses, here the results of the study of five particularly well exposed uppermost Pliensbachian and Lower-Middle Toarcian sections, located in northern and central Spain: the West Rodiles section, located in the
Asturias province, in northern Spain, the Tudanca and the San Andres sections, located in the Basque-Cantabrian Basin of northern Spain, and the La Almunia and the Sierra Palomera sections, located in the Iberian Range of central Spain are presented (Fig. 1a and b). In all sections, detailed ammonite-based biostratigraphy, coupled with stable isotope analysis of belemnite calcite and bulk carbonates, as well as total organic carbon (TOC) analyses have been performed. Records of the vertical distribution of mainly benthic fossils have been compiled in four of the studied sections, and results obtained in the Spanish outcrops have been compared and correlated with other European sections.

\section{Materials and methods}

The five sections have been studied bed by bed and collected ammonites were prepared and studied following the conventional methods. Obtained biostratigraphy allowed characterization of the standard chronozones and subchronozones, which are used in this work. A total of 233 analyses of stable isotopes were performed on 182 belemnites, in order to obtain the primary uppermost Pliensba- chian and Early/Middle Toarcian seawater stable isotope signal, and hence to determine palaeotemperature variations. In addition, 218 bulk carbonate samples were collected and 296 analyses of $\mathrm{C}$ and $\mathrm{O}$ isotope were carried out and a total of 146 samples were analyzed for TOC content.

For the assessment of possible burial diagenetic alteration of the collected belemnites, polished samples and thick sections of each belemnite rostra were prepared. The thick sections were studied under the petrographic and the cathodoluminescence microscope, and only the non-luminescent portions of the belemnite rostra were sampled using a microscope-mounted dental drill. Sampling of the luminescent parts such as the apical line and the outer phragmocone wall, fractures, and borings have been avoided. Additionally, 30 belemnite calcite samples were analyzed using X-ray diffraction techniques to make sure that no other minerals except for calcite were present in the samples.

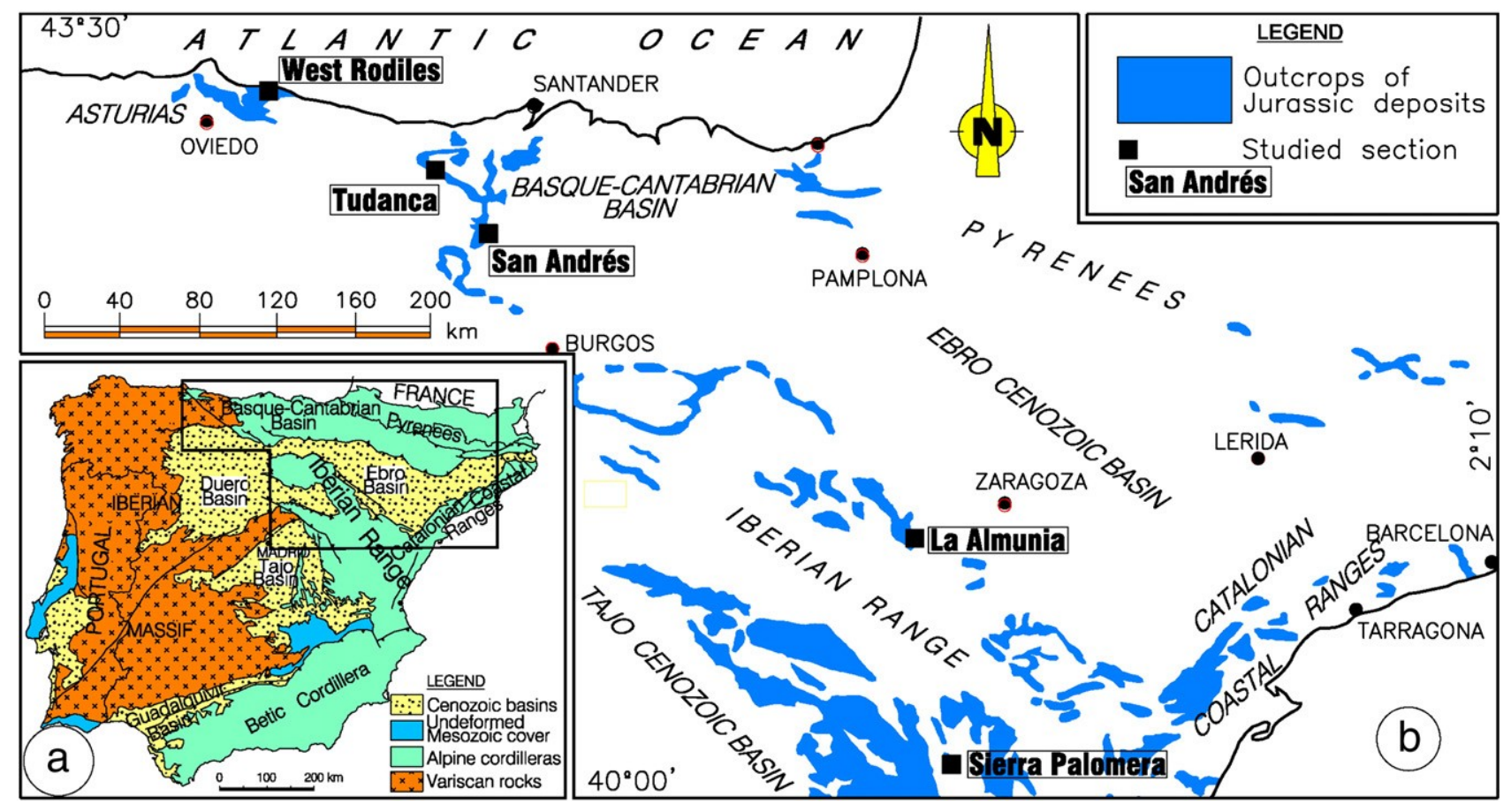

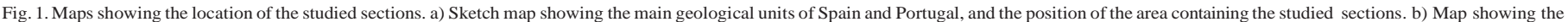
outcrops of the Jurassic deposits in northern and central Spain and the location of the five studied sections. 
Some of the belemnites collected at La Almunia were analyzed for stable isotopes in the Salamanca University (Spain) and the remaining belemnite and bulk rock samples were processed in the Michigan University (USA).

For stable isotope analysis, carbonate samples weighing a minimum of $10 \mu \mathrm{g}$ were placed in stainless steel boats. Samples were roasted at $200{ }^{\circ} \mathrm{C}$ in vacuum for $1 \mathrm{~h}$ to remove volatile contaminants and water. Samples were then placed in individual borosilicate reaction vessels and reacted at $77^{\circ} \pm 1{ }^{\circ} \mathrm{C}$ with 3 or 4 drops of anhydrous phosphoric acid for 8 min in a Finnigan MAT Kiel IV preparation device coupled directly to the inlet of a Finnigan MAT 253 triple collector isotope ratio mass spectrometer. $\mathrm{O}^{17}$ corrected data are corrected for acid fractionation and source mixing by calibration to a best-fit regression line defined by two NBS standards, NBS 18 and NBS 19. Precision and accuracy of data were monitored through daily analysis of powdered carbonate standards. At least six standards were analyzed daily, bracketing the sample suite at the beginning, middle, and end of the day's run. In all samples, isotope ratios are reported in per mil relative to the standard Peedee belemnite (PDB). Several samples were analyzed in both laboratories, having a reproducibility better than $0.4 \%$ PDB for $\delta^{13} \mathrm{C}$ and better than $0.6 \%$ PDB for $\delta^{18} \mathrm{O}$. Internal analytical precision in belemnite carbonates was

$\pm 0.04 \%$ o for both $\delta^{13} \mathrm{C}$ and $\delta^{18} \mathrm{O}$, and internal analytical precision in bulk carbonates was $\pm 0.04 \%$ for $\delta^{13} \mathrm{C}$ and $\pm 0.09 \%$ o for $\delta^{18} \mathrm{O}$.

The Toarcian seawater palaeotemperature recorded in the studied belemnite rostra have been calculated using the Anderson and Arthur (1983) equation: T $\left({ }^{\circ} \mathrm{C}\right)=16.0-4.14\left(\delta_{\mathrm{c}}-\delta_{\mathrm{w}}\right)+0.13\left(\delta_{\mathrm{c}}-\delta_{\mathrm{w}}\right)^{2}$ where $\delta_{\mathrm{c}}=\delta^{18} \mathrm{OPDB}$ is the composition of the sample, and $\delta_{\mathrm{w}}=\delta^{18} \mathrm{OSMOW}$ the composition of ambient seawater. Normal values of $\mathrm{S}=34.3 \%$ for the marine salinity (Wright, 1987) and $\delta_{\mathrm{w}}$ values of $-1 \%$ for a non- glacial ocean water (Sackleton and Kennet, 1975), were used. For palaeotemperature calculation, it has been assumed that the $\delta^{18} \mathrm{O}$ values, and consequently the resultant curve, essentially reflects changes in environmental parameters (Sælen et al., 1996; McArthur

et al., 2007; Price et al., 2009; Rexfort and Mutterlose, 2009), as the sampled non-luminescent biogenic calcite of the studied belemnite rostra precipitated in equilibrium with the seawater. It was also assumed that the biogenic calcite retains the primary isotopic composition of the seawater and that the sampling bias, vital effects, skeletal growth and belemnite migration are not the main factors responsible for the obtained variations.

TOC analyses have been performed in the Centro de Espectrome- tría Atómica of the Universidad Complutense de Madrid using a Shimadzn TOC-V analyzer for solid samples (SSM-5000 A). One sample of standard NIST 1944 was analyzed every four samples of rock to control the total carbon values and bicarbonate of soda for the inorganic carbon. Analytical error was better than $\pm 0.7 \%$.

For the structure of the mass extinction event, the Kauffman and Erwin (1995) model was used. The extinction interval is characterized by extinction rates that are higher than the origination rates, giving rise to a decrease in the diversity of the community. In the mass extinction boundary extinction rate reaches the highest value and originations are minimal. During the repopulation interval, originations progressively increase and the assemblages are dominated by new evolved species andsurvivingtaxa.

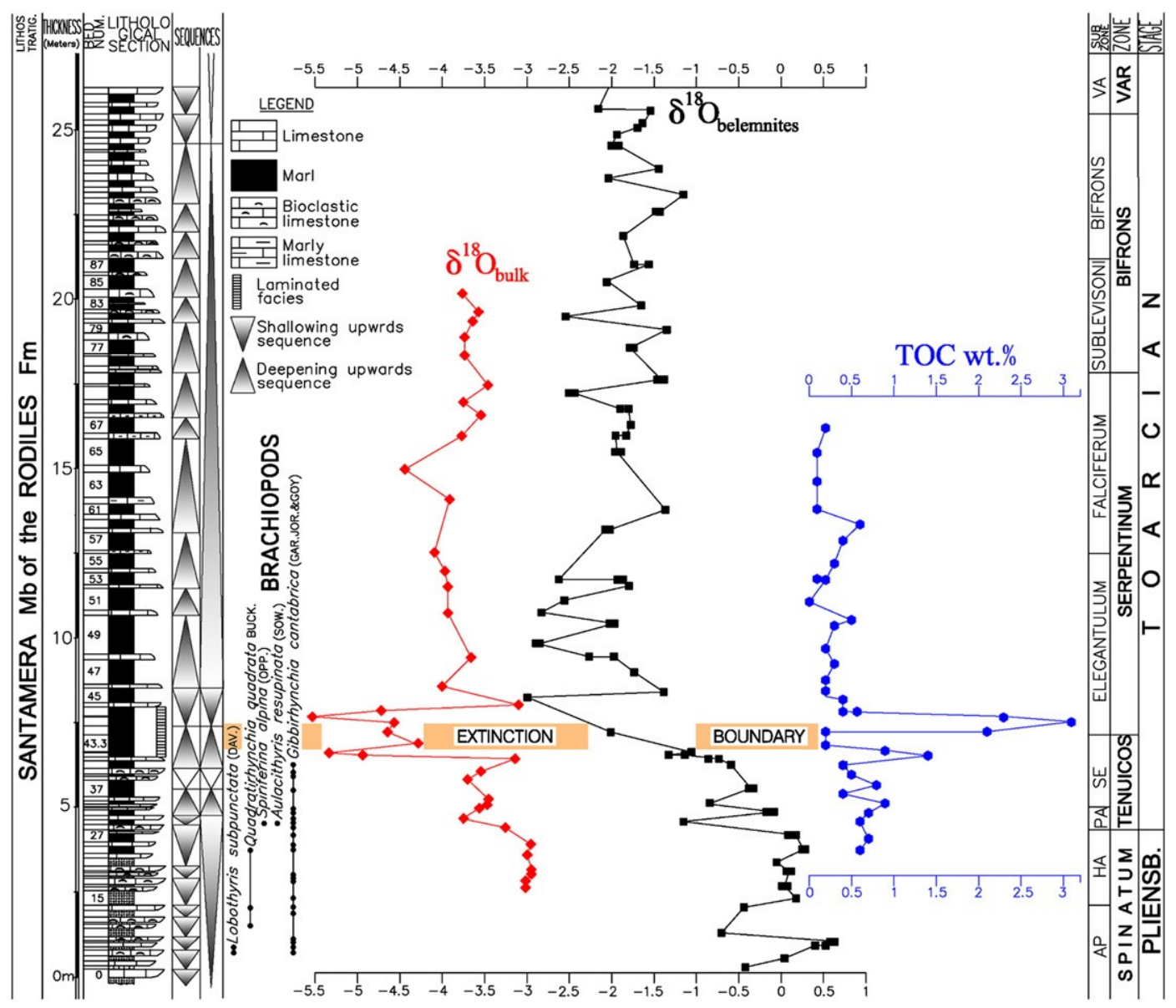

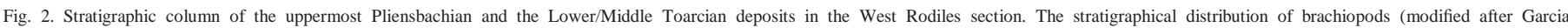

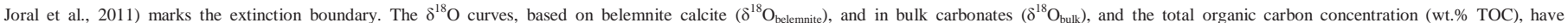

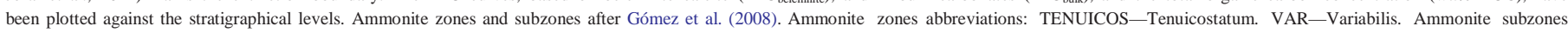
abbreviations: AP-Apyrenum. HA-Hawskerense. PA-Paltum. SE-Semicelatum. VA-Variabilis. 


\section{Sections from northern and central Spain}

\subsection{West Rodiles section}

In the coastal cliffs of the eastern part of the Asturias region, in Northern Spain (Fig. 1b), the well exposed Early Toarcian deposits are represented by a succession of alternating lime mudstone and marl (Fig. 2) belonging to the Santa Mera Member of the Rodiles Formation (Valenzuela, 1988). The ammonitebased chronostratigraphical subdivi- sions of the Toarcian deposits in Asturias have been carried out by Suárez- Vega (1974), Goy et al. (1997), Gómez et al. (2008) and Goy et al. (2010). Profiles of the $\delta^{18} \mathrm{O}_{\text {belemnite }}$ values obtained from belemnite calcite

and of $\delta^{18} \mathrm{O}_{\text {bulk }}$ obtained from bulk carbonates have been plotted against

the stratigraphic levels of the West Rodiles section (Fig. 2). The $\delta^{18} \mathrm{O}_{\text {belemnite }}$ values are progressively more negative from the upper- most Pliensbachian through the lowermost Toarcian Tenuicostatum Zone. A significant excursion toward more negative values starts around the Tenuicostatum-Serpentinum zonal boundary (the extinction boundary), and develops in the Serpentinum and in the Bifrons zones, reaching peak values around-2.9\%, intheElegantulumSubzone. Even

the lower part of the curve shows some similarities in its general trend

respect to the $\delta^{18} \mathrm{O}_{\text {belemnite }}$ curve, the $\delta^{18} \mathrm{O}_{\text {bulk }}$ values mainly reflect the signal acquiredduring burial diagenesis.

The TOC content of the uppermost Pliensbachian and the Lower Toarcian marls is generally lower than $1 \mathrm{wt} . \%$, with a peak value of up to 3.2 wt.\% TOC, which is located above the Tenuicostatum-Serpenti- num zonal boundary. One meter thick thinly laminated facies are only recorded above and below this zonal and extinction boundary (Fig. 2), but the remaining deposits are bioturbated.

\subsection{Tudanca section}

The Tudanca section is located near the village of Tudanca, situated about 60 $\mathrm{km}$ southwest of the Santander city (Fig. 1b). The outcrops are located in the western limit of the Basque-Cantabrian Basin, which represents the western extension of the Pyrenees folded and thrusted belt (Fig. 1a). The Upper Pliensbachian and the Lower-Middle Toarcian deposits outcrop along several well-exposed path cuts, on which the section has been studied bed by bed. The uppermost Pliensbachian and the lowermost Toarcian are represented by the alternation of marl and lime mudstone of the Castillo Pedroso Formation (Quesada et al., 2005). The ammonite chronostratigraphy allows subdivisions at the subzone scale (Goy et al., 1994, this work).

Variations of stable isotope values in belemnite calcite and in bulk carbonates, plotted against the stratigraphic levels, show the progressive decrease of the $\delta^{18} \mathrm{O}_{\text {belemnite }}$ values throughout the uppermost Pliensba- chian and the lowermost Toarcian (Tenuicostatum Zone). A sharp shift toward more negative values is recorded above the Tenuicostatum- Serpentinum zonal boundary (Fig. 3). The $\delta^{18} \mathrm{O}_{\text {bulk }}$ values largely reflect
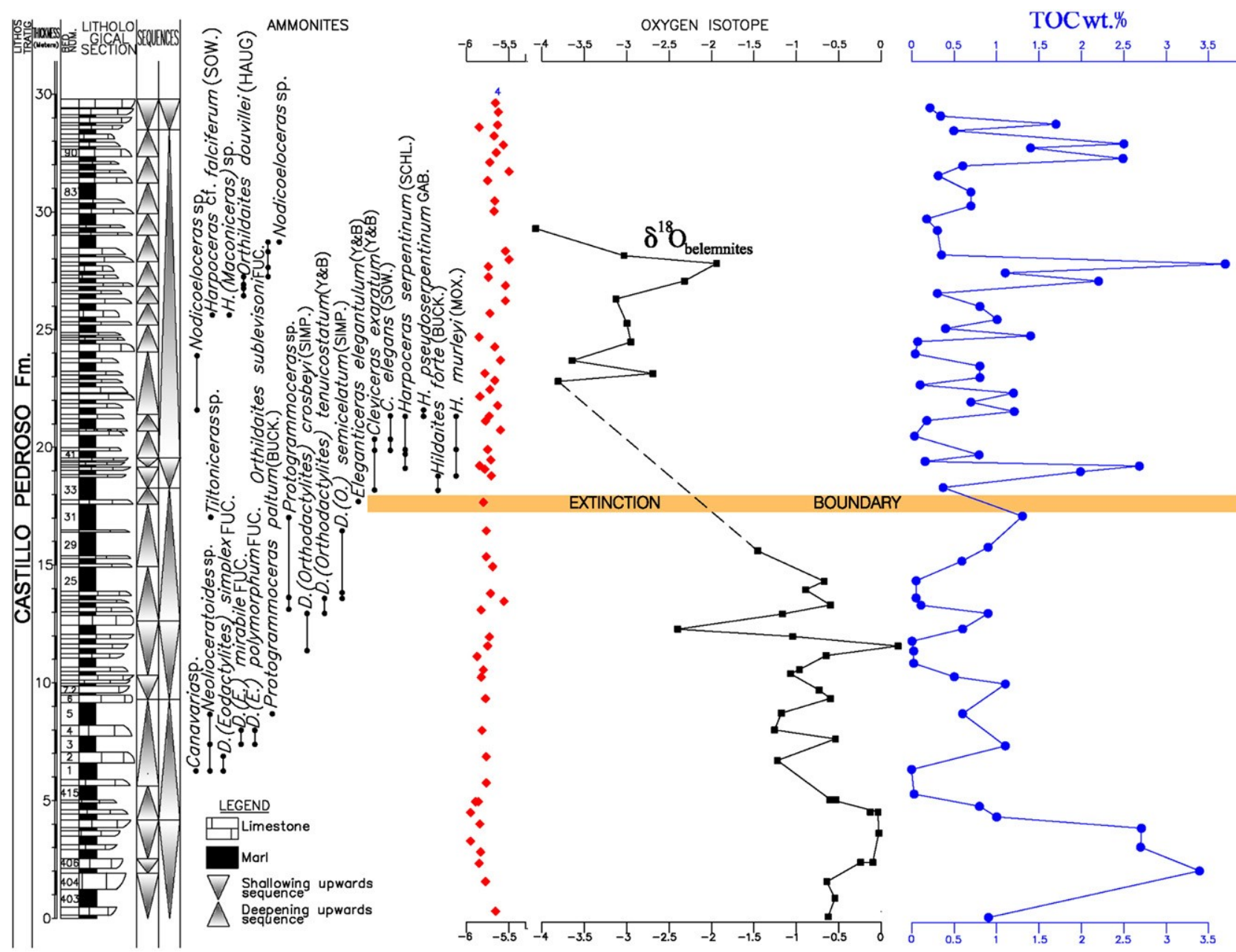
the signal of the diagenetic overprint affecting the carbonate sediments of this area, which is represented by flat values around -5.5 to $-6 \%$.

Seventy percent of the samples from Tudanca show TOC values

below $1 \mathrm{wt.} \%$, with several peaks showing higher values. The lowest peak in the section is located in the uppermost Pliensbachian Spinatum Zone, where values up to $3.4 \mathrm{wt}$ \% TOC were obtained, and another peak has been recorded in the lower Serpentinum Zone, above the extinction boundary. Two additional peaks are recorded: one at the Lower-Middle Toarcian boundary (Serpentinum-Bifrons zonal boundary), with peak value of $3.8 \mathrm{wt} \%$ TOC, and another peak at the Bifrons Zone. Neither laminated facies nor black shales have been found in this section.

\subsection{San Andres section}

The San Andres section is located in the southwestern part of the BasqueCantabrian Basin (Fig. 1b). The uppermost Pliensbachian and the Lower-Middle Toarcian are represented by the alternation of lime mudstone and marl of the Castillo Pedroso Formation and the ammonite content allowed subdivision at the zone and subzone level (Fig. 4).

Stable isotope records obtained on belemnite calcite are restricted to the uppermost Pliensbachian and the lowermost Toarcian Tenuicos- tatum Zone. In the Serpentinum Zone, above the extinction and zonal boundary, belemnites as well as benthic organisms such as brachiopods (García Joral et al., 2011) are very rare or non-existent. The $\delta^{18} \mathrm{O}_{\text {belemnite }}$ values are moderately negative throughout the Tenuicostatum Zone and tend to reach more negative values around the Tenuicostatum- Serpentinum zonal boundary. The $\delta^{18} \mathrm{O}_{\text {bulk }}$ values are strongly affected by burial diagenesis, as indicated by the very negative values, which tend to be less negative at the extinction boundary, showing an opposite trend respect to the $\delta^{18} \mathrm{O}_{\text {belemnite }}$ curve.

The distribution of the TOC content shows that most of the samples reflect values below 1 wt.\%, with 3 small peaks of up to 1.5 wt.\% TOC (Fig. 4). The lowermost peak is restricted to the Semicelatum Subzone, the extinction boundary coincides with a minimum in the TOC values, and three small peaks, defined by single samples, are recorded in the Lower Toarcian Elegantulum Subzone and in the Middle Toarcian Sublevisoni Subzone.

\subsection{La Almunia section}

The La Almunia section is located in the Iberian Range of central- eastern Spain (Fig. 1a and b). The uppermost Pliensbachian and the lowermost part of the Toarcian is represented by the bioclastic

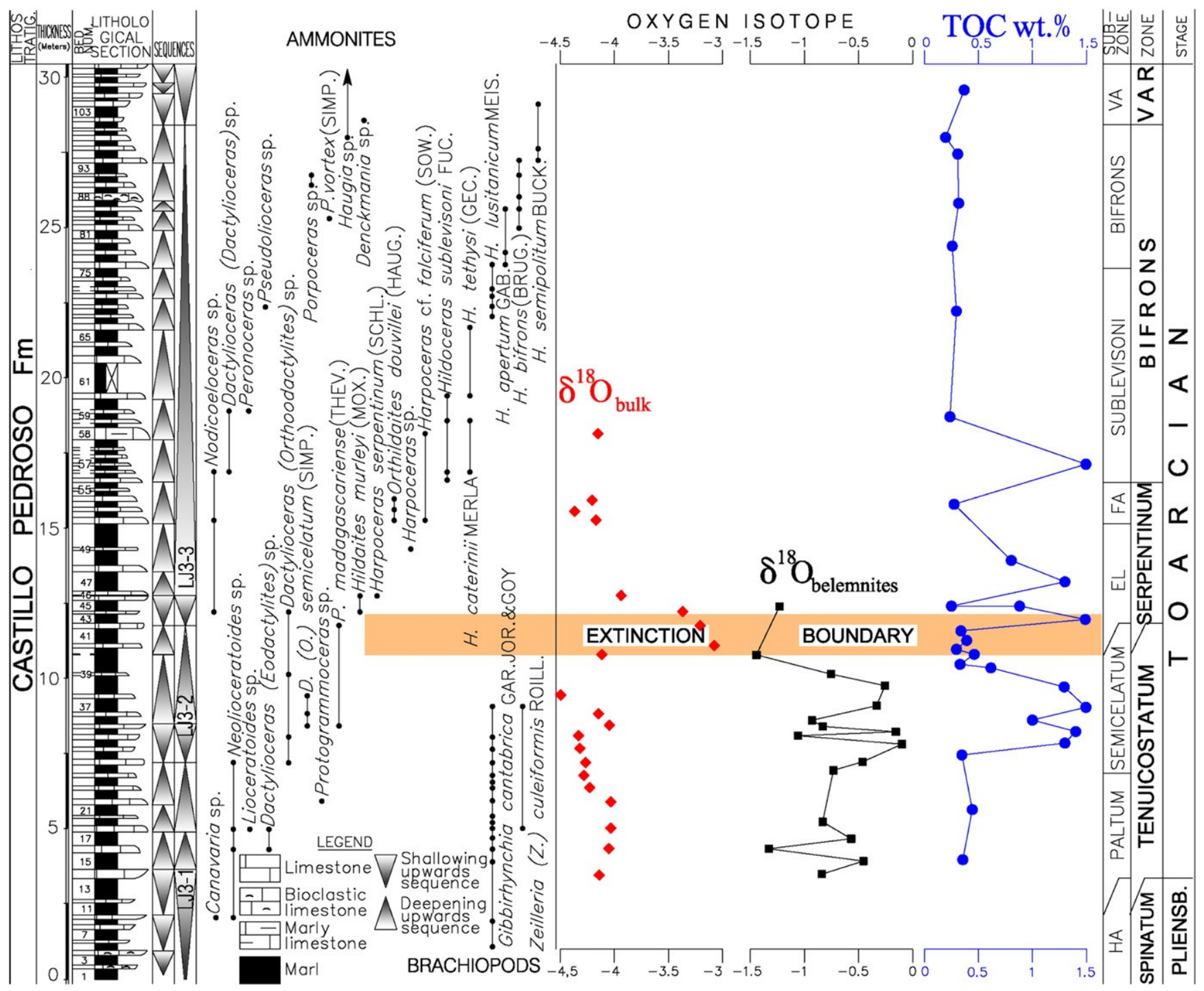

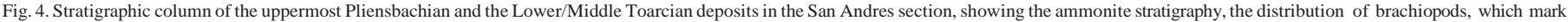

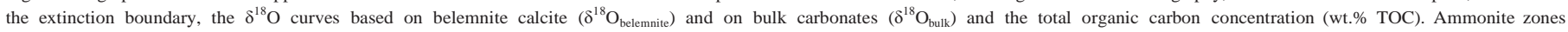
abbreviations: VAR —Variabilis. Ammonite subzones abbreviations: HA—Hawskerense. EL—Elegantulum. FA—Falciferum. VA—Variabilis. 
wackestone to packstone limestone of the Barahona Formation, but most of the Lower and Middle Toarcian is represented by the hemipelagic alternating lime mudstone and marl of the Turmiel
Formation (Fig. 5). Ammonite biostratigraphy at the subzone scale has been based on the studies of Goy and Martínez (1990), Goy et al. (1996) and Gómez et al. (2008).

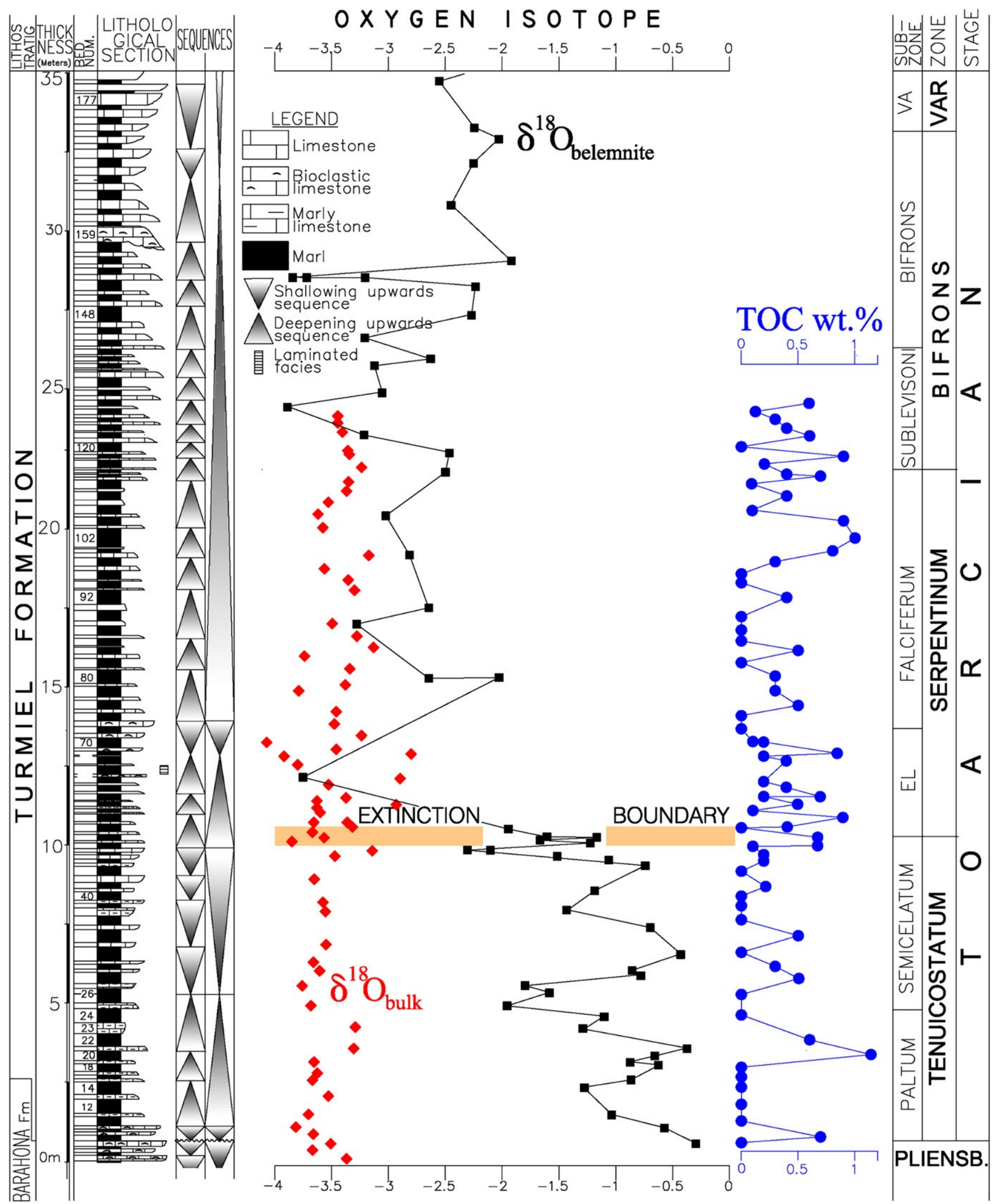

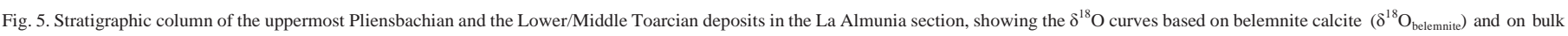

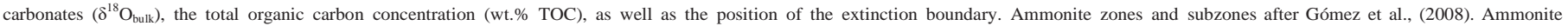
zones abbreviations: VAR—Variabilis. Ammonite subzones abbreviations: EL—Elegantulum. VA—Variabilis. 


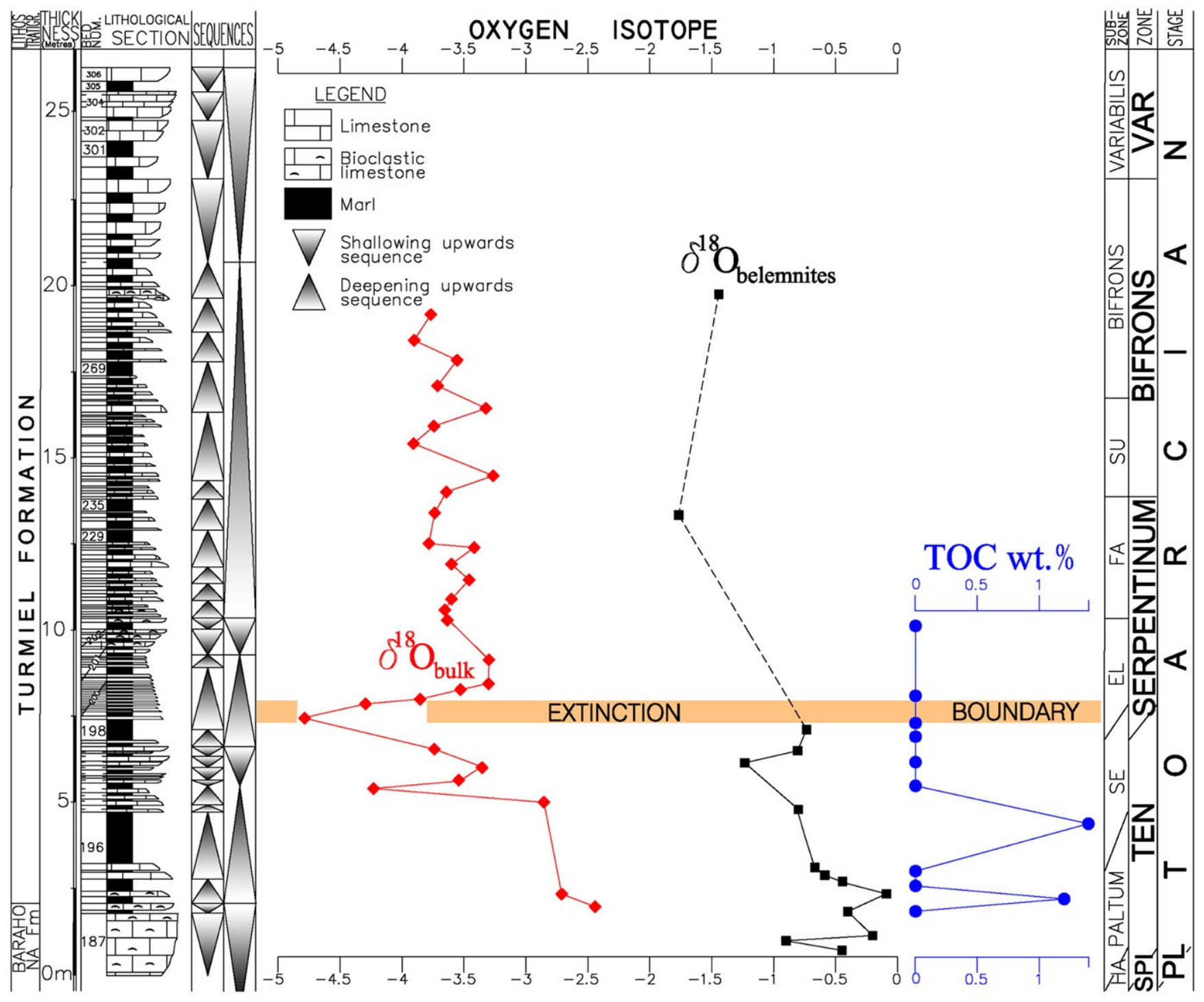

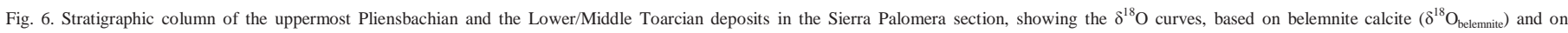

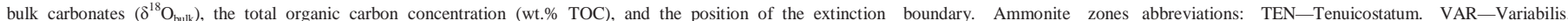
Ammonite subzones abbreviations: HA-Hawskerense. SE-Semicelatum. EL-Elegantulum. FA-Falciferum. SU—Sublevisoni.

Plotting of the stable isotope values obtained from belemnite calcite and from bulk carbonates, against the stratigraphical levels, shows that at the uppermost Pliensbachian and the lowermost Toarcian (Tenuicostatum Zone), the $\delta^{18} \mathrm{O}_{\text {belemnite }}$ values are decreas-

ing toward more negative figures. The $\delta^{18} \mathrm{O}_{\text {belemnite }}$ values of $-0.29 \%$ recorded at the uppermost Pliensbachian, decrease to average values of $0.86 \%$ in the Paltum Subzone and to average values of $-1.36 \%$ in the Semicelatum Subzone. The Tenuicostatum-Serpentinum zonal boundary (Fig. 5) marks the onset of a noteworthy excursion toward more negative values that reaches average $\delta^{18} \mathrm{O}_{\text {belemnite }}$ values of

- 2.60\% in the Serpentinum zone. The $\delta^{18} \mathrm{O}_{\text {bulk }}$ values obtained from carbonates are quite uniform, showing an average value of $-0.36 \%$, which reflects the signal acquired during burial diagenesis.
A total of 75 levels of marls have been analyzed for TOC content. All samples of the interval supposedly corresponding to the ETOAE show values always less than 1 wt.\% TOC and more than a half of the samples contain less than 0.5 wt.\% TOC (Fig. 5). All the deposits of the studied interval are bioturbated, and only a $30 \mathrm{~cm}$ thick marl level of the Serpentinum Zone shows laminations (Fig. 5).

\subsection{Sierra Palomera section}

The Sierra Palomera section (Fig. 1b), has been studied along the Rambla del Salto creek. The lithostratigraphical units corresponding to the uppermost Pliensbachian and the Lower-Middle Toarcian, are the bioclastic wackestone to packstone limestone of the Barahona

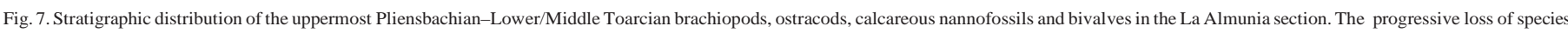

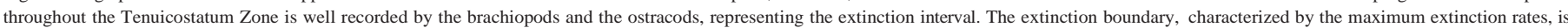

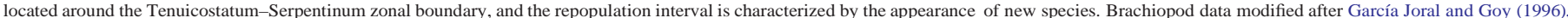

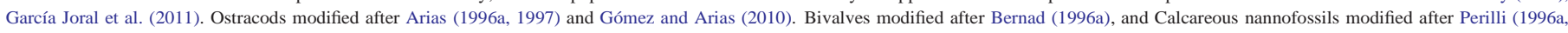
2000). Ammonite subzone abbreviation: EL-Elegantulum Subzone. 


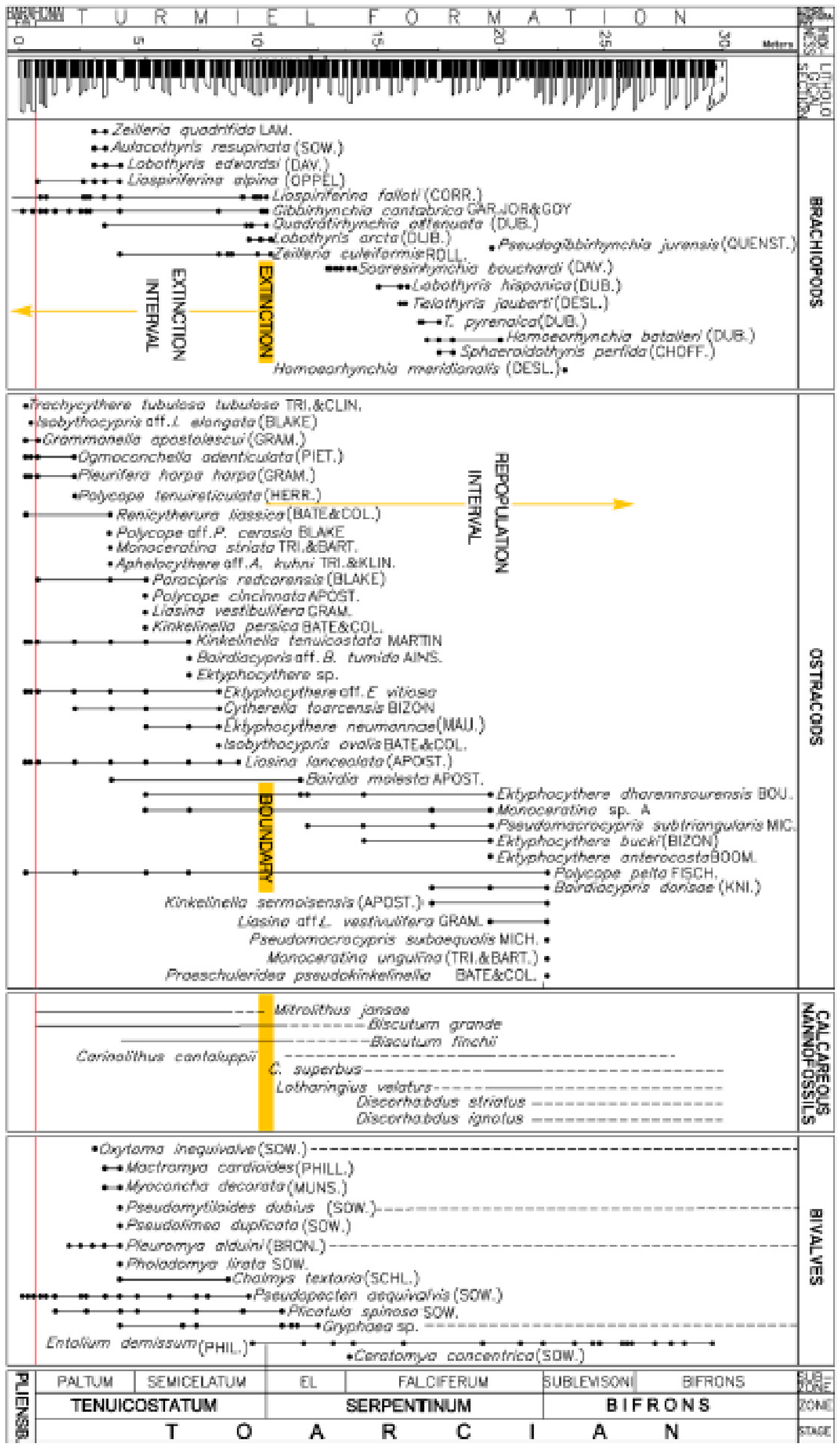


Formation, and the alternating lime mudstone and marl of the Turmiel Formation (Fig. 6). The ammonite biostratigraphy, at the subzone scale, is based on ComasRengifo et al. (1996) and Osete et al. (2007).

At Sierra Palomera, belemnites are extremely scarce above the Tenuicostatum-Serpentinum zonal and extinction boundary. Only a very low resolution isotopic record, based on belemnite calcite, can be obtained above this boundary (Fig. 6). The $\delta^{18} \mathrm{O}_{\text {belemnite }}$ values show a progressive decrease through the Tenuicostatum Zone. Average values are $-0.46 \%$ in the Paltum Subzone and $-0.79 \%$ in the Semicelatum Subzone. The scarce values above the Tenuicostatum-Serpentinum

zonal boundary mark a trend toward more negative values. The isotopic values obtained from bulk carbonates $\left(\delta^{18} \mathrm{O}_{\text {bulk }}\right)$ reveal the effect of burial diagenesis, in agreement with the luminescent character of the carbonates, reaching values up to $-4.86 \%$. Nevertheless, $\delta^{18} \mathrm{O}_{\text {bulk }}$ values tend to delineate a similar trend than the oxygen isotope curve

obtained from belemnite calcite. The values tend to be progressively more negative through the Tenuicostatum Zone, reaching the peak of the negative excursion around the Tenuicostatum-Serpentinum zonal boundary. Except for two samples that returned values up to $1.5 \mathrm{wt}$ \% TOC, analysis of the Lower Toarcianmarlbedsreflectsthelack of organic carbon in this part of the section.

4. The record of the Early Toarcian mass extinction in central and northern Spain

According to the Kauffman and Erwin (1995) model, the stratigraphical distribution of benthic and nektonic fossils in the La Almunia section, clearly illustrates the stratigraphical position of the extinction interval, the extinction boundary and the repopulation interval, (Fig. 7). In the lower part of the Tenuicostatum Zone, $44 \%$ of the species of brachiopods disappeared and the remaining 55\% become extinct at the TenuicostatumSerpentinum zonal and extinction boundary. After an interval of about 0.5 Myr with no new originations, the platform was repopulated by opportunistic species of brachiopods (García Joral et al., 2011), marking the onset of the repopulation interval. Ostracods are also excellent indicators of the extinction event. From a total of 35 taxa of ostracods identified at La Almunia, 26 taxa appeared before the Tenuicostatum-Serpentinum zonal boundary, 22 taxa (85\%) progressively disappear during the Early Toarcian Tenuicostatum Chronozone, marking the extinction interval, while only 4 (15\%) surpassed this boundary. After an interval probably equivalent to the early part of the Elegantulum Chronozone, in which no new appearances were recorded, 8 taxa were progres- sively originated during the repopulation interval (Arias 1996a; Gómez and Arias, 2010). At a lesser extent, also calcareous nannofossils (Perilli, 1996a) and bivalves (Bernad, 1996a) are indicators of the extinction event.

Stratigraphical distribution of some of the fossil groups at Sierra Palomera (Fig. 8), plotted against the stratigraphical section and the ammonites zones and subzones, allows definition of the extinction and the repopulation intervals, as well as the setting down of the extinction boundary. None of the 9 species of brachiopods found in the uppermost Pliensbachian and the lowermost Toarcian beds surpass the Tenuicostatum-Serpentinum zonal and extinction bound- ary. Appearance of new species of brachiopods, marking the onset of the repopulation interval, occurs in the lower part of the Elegantulum Subzone (García Joral et al., 2011). From the 34 taxa of foraminifers that had their appearance before the extinction boundary, 16 taxa
(47\%) progressively disappeared throughout the extinction interval, and the remaining 17 species passed this boundary, marking the survival interval (Herrero, 2001). Ostracods also show a progressive drop in the number of species throughout the Tenuicostatum Zone (Arias, 1996b; Gómez and Arias, 2010). From the 13 taxa originated before the Tenuicostatum-Serpentinum zonal boundary, 10 taxa (77\%) progressively disappeared, marking the extinctioninterval and

3 taxa survived, marking the survival interval. Ostracods slowly recovered after the extinction boundary and 5 new taxa had their first appearance (FA) before the Middle Toarcian (Fig. 8). Calcareous nannofossils also recorded a significant renewal. Two of the 4 species that had their FA before the extinction boundary disappeared and 5 FAs were recorded after this boundary, representing the repopulation interval (Perilli, 1996b).

In the West Rodiles and the San Andres sections, in northern Spain, the extinction interval and the extinction boundary are also well marked by the total disappearance of brachiopods (Figs. 2 and 4). These organisms did not colonize again these platforms before the Middle Toarcian Variabilis Zone, well above the studied interval (García Joral et al., 2011).

In all the studied sections, the extinction pattern is very consistent. There is a progressive loss of species throughout the lowermost Toarcian Tenuicostatum Zone, marking the extinction interval, with a sudden increase in the extinction rate indicated by the disappearance of numerous species around the Tenuicostatum-Serpentinum zonal boundary, which marks the extinction boundary, and a subsequent recovery which marks the repopulation interval.

\section{Discussion}

\subsection{Comparison of the TOC records and the postulated Early Toarcian Oceanic Anoxic Event}

TheEarly Toarcian Oceanic Anoxic Event(ETOAE), was defined by Jenkyns (1988) as a period of time characterized by abnormally high depositional and preservational rates of organic carbon in favorable marine environments, due to widespread anoxia, that gave rise to the synchronous deposition of black shale facies in many parts of the globe (Jenkyns 1988; Jenkyns et al., 2002). According to this definition, the anoxic environments linked to the ETOAE are marked in the stratigraphical record by the presence of synchronous black shale deposits. According to Bates and Jackson (1987), Kearey (2001) and McArthur et al. (2008), black shale facies should only be considered those shales where total organic carbon (TOC) content is above 5 wt.\%. Based on this definition, compilation of data from the European sections indicate that real black shale facies having more than $5 \mathrm{wt} . \%$ TOC are constrained to a sub-basin of the European Epicontinental Sea, on which euxinic facies were developed during Early-Middle Toarcian. This sub-basin, which extends throughout Eastern UK, North Sea, Germany and Northern France (Fig. 9), is here named as the Western Europe Euxinic Basin (WEEB). In other parts of the European Epicontinental Sea, as in many parts of the globe, Early Toarcian marine black shale facies are rare to absent. Most of the Lower Toarcian European and Northern African sections are constituted by bioturbated deposits commonly containing a well diversified fauna and less than 1 wt.\% TOC, indicating oxygenated depositional environments (Figs. 9 and 10$)$.

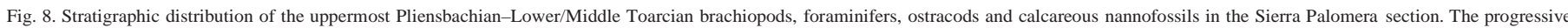

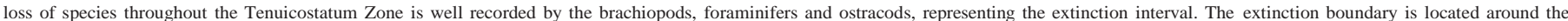

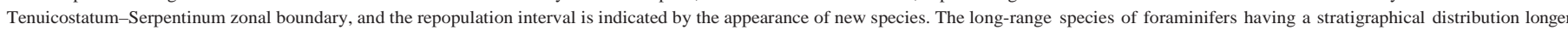

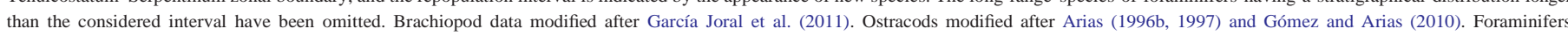

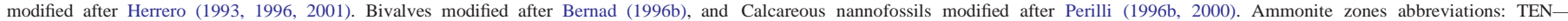
Tenuicostatum. VAR—Variabilis. Ammonite subzones abbreviations: HA - Hawskerense.SE—Semicelatum.EL—Elegantulum.FA—Falciferum.SU—Sublevisoni. 


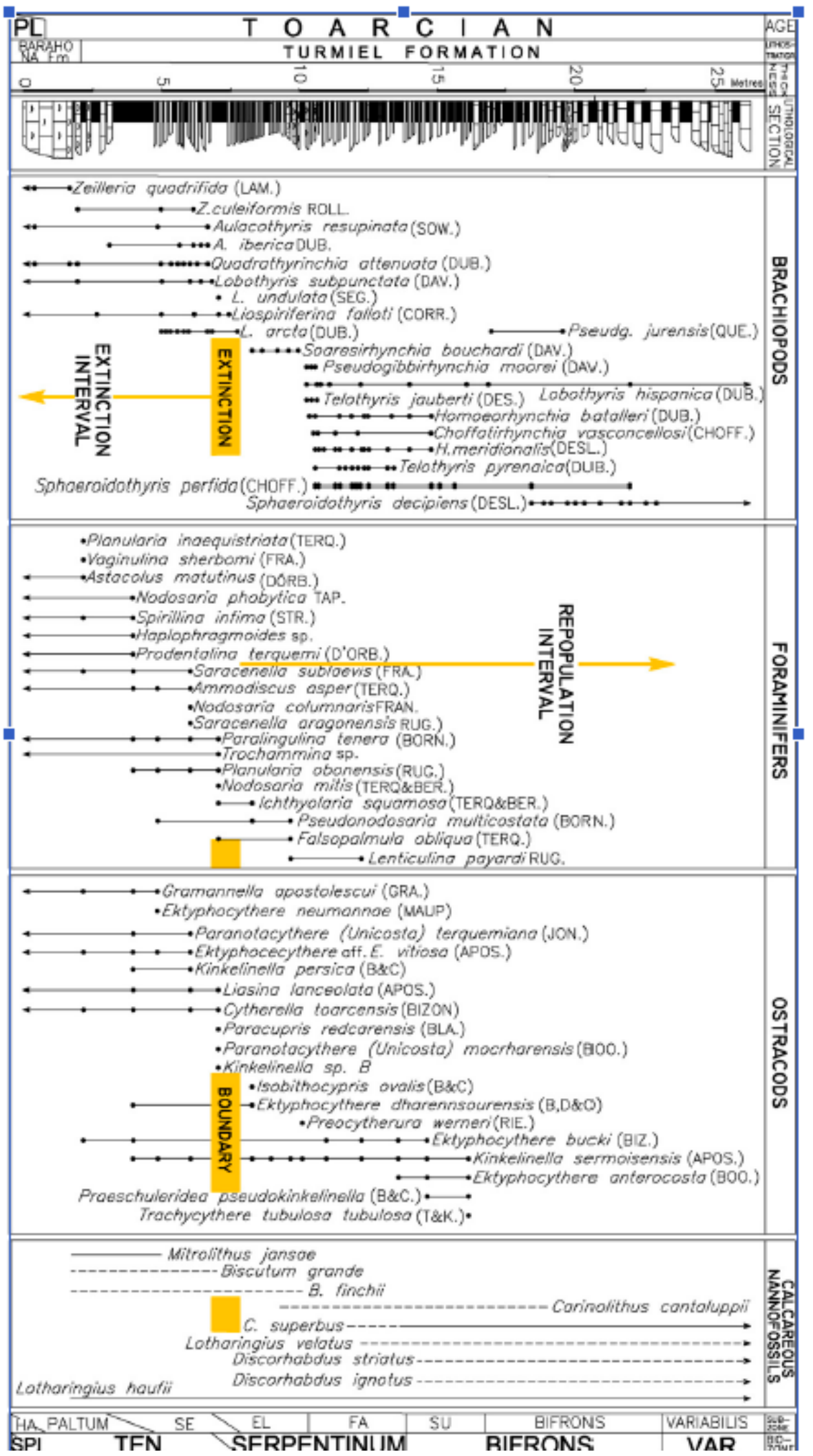




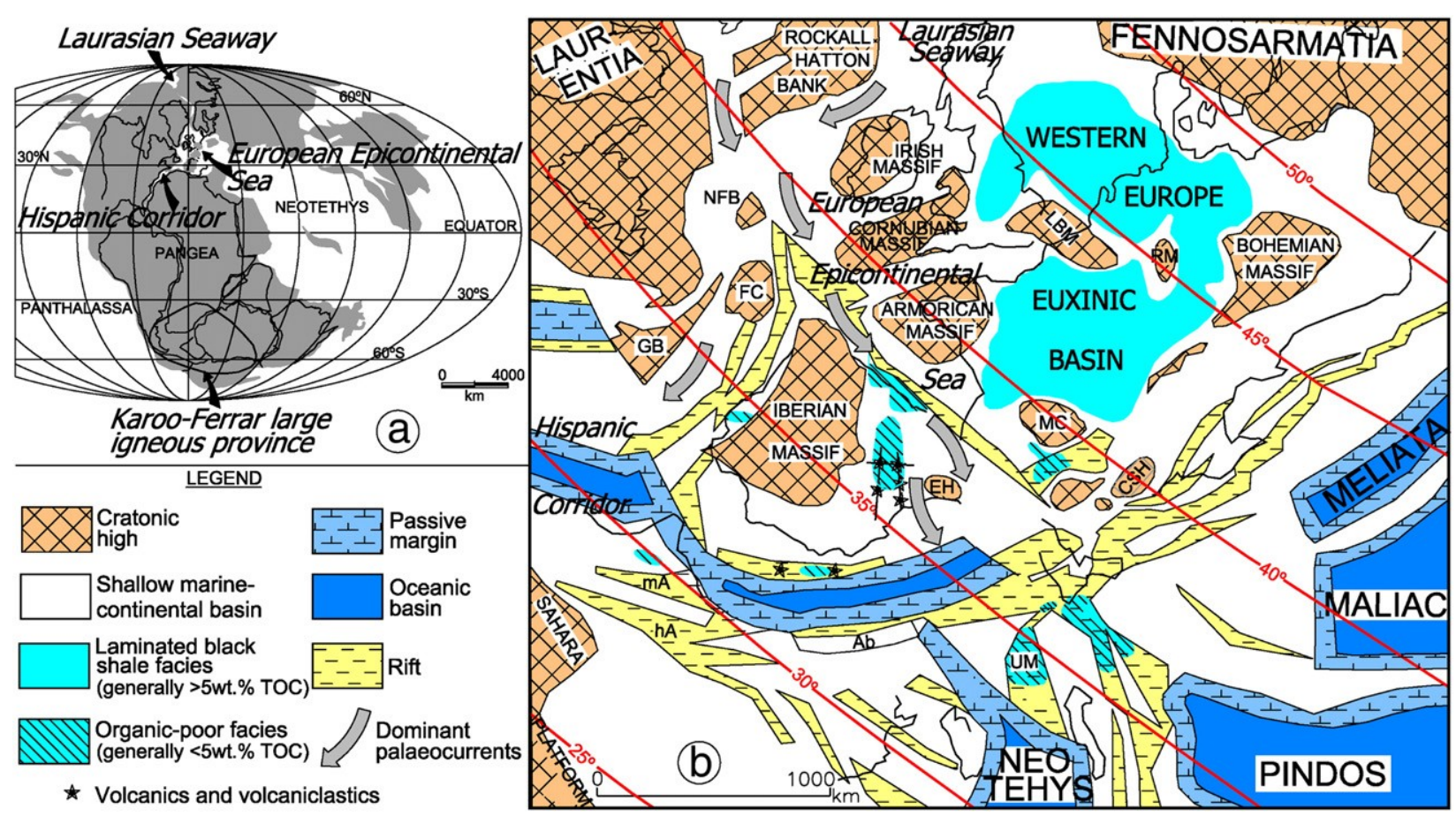

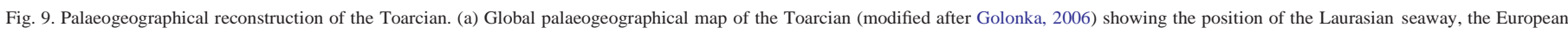

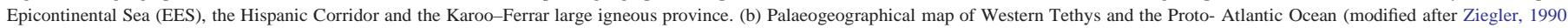

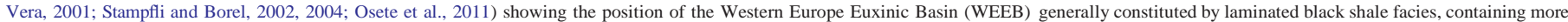

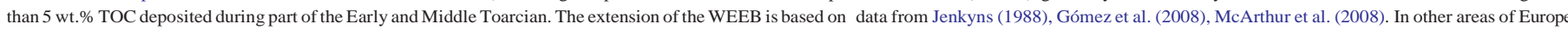

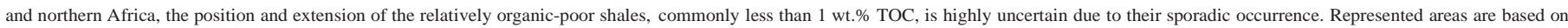

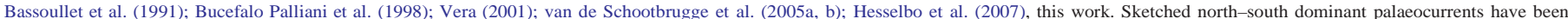

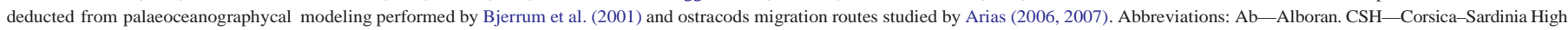

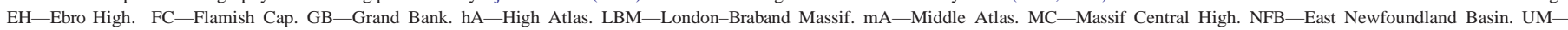
Umbria- Marche.

The constriction of the laminated anoxic black shale facies to the WEEB, indicates that the ETOAE cannot be considered as an oceanic event, in the sense of an anoxic episode of global extent, but a phenomenon of regional extent. For this purpose, the more appro- priated name of Regional Anoxic Event (RAE) has been proposed by McArthur (2007) and McArthur et al. (2008) to nominate the event that generated the presence of laminated black shales during the Early to Middle Toarcian in the WEEB. This sub-basin could possibly be considered as a partly silled basin, to a certain extent semienclosed by the surrounding emerged lands, that resulted in the stagnation of significantly stratified seawater masses, which were strongly restrict- ed as indicated by the Mo/TOC profiles (McArthur et al., 2008), under greenhouse conditions.

No real black shale facies were found in the studied sections. TOC values up to $3 \mathrm{wt} . \%$ were found only in one sample, and values of $1 \mathrm{wt}$.

$\%$ TOC were only occasionally surpassed (Fig. 10a). Laminated deposits, indicating possible suboxic to anoxic conditions, were only found at the extinction boundary in the West Rodiles section (1 m thick), and a $30 \mathrm{~cm}$ thick level in the Elegantulum Subzone, in the La Almunia section, above the extinction boundary. Most of the Lower Toarcian deposits in the Spanish sections show bioturbated facies, indicative of well oxygenated oxidizing bottom waters (Savrda and Bottjer, 1986; Kemp, 1996) and a well diversified benthonic fauna (Figs. 7 and 8). In addition, the small TOC peaks in the Spanish sections are diachronous. Those peaks are located below the extinction boundary, like at Sierra Palomera, above the extinction boundary, like at West Rodiles and at Tudanca, or above and below this boundary, like at San Andres or at La Almunia (Fig. 10a). In other areas of Europe, the peak TOC values are also diachronous respect to the standard ammonites zones and subzones (Fig. 10b), as pointed out by many authors (Wignall et al., 2005; Gómez et al., 2008; McArthur et al., 2008), and consequently cannot be used as stratigraphical markers.

When comparing the TOC values of the European sections (Fig. 10b), only the Yorkshire (UK) and the Dotternhousen (Germany) sections, representatives of the WEEB, have organic carbon values largely surpassing the cut-off grade of 5 wt.\%. The Portuguese, Italian and Spanish sections show values generally well below 5 wt.\% TOC. Even in the WEEB, the precise timing of the onset of the deposition of the anoxic laminated black shales is difficult to determine in some cases. In Yorkshire, TOC values above the 5 wt.\% are reached at the upper Tenuicostatum Zone, using the Hesselbo et al. (2000) data, or at the Falciferum (Serpentinum) Zone, using the McArthur et al. (2008) data. At Dotternhousen (Germany), deposition of anoxic laminated black shale facies started at the uppermost Tenuicostatum Zone (Semicelatum Subzone), but several organic-poor intervals are interbedded, and two thin episodes of distinctly laminated black shales containing above 5 wt.\% TOC are recorded at the lower and middle Tenuicostatum Zone (Röhl et al., 2001; Schmid-Röhl et al., 2002). In both areas, black shale deposition in the WEEB continued up to the Bifrons Zone, representing a time interval of about $1.5 \mathrm{Myr}$ but the end of deposition of black shale facies is diachronous at the subzone level. The low TOC values, commonly below 1 wt.\%, recorded at the Lower Toarcian sections in southern and western UK (Jenkyns and Clayton, 1997; Jenkyns et al., 2002), in the Lusitanian Basin of Portugal (Hesselbo et al., 2007a), in the Betic Cordillera of southern Spain (Jiménez et al., 1996), in Italy in the Pozzale section (Parisi et al., 1996; Bucefalo Palliani et al., 1998), in the Northern Apennines (Perilli et al., 2009), in the Valdorbia section (Sabatino et al., 2009), in other sections of Italy (Jenkyns and Clayton, 1986), and in the sections of northern Morocco (Bassoullet et al., 1991; Bodin et al., 2010), 

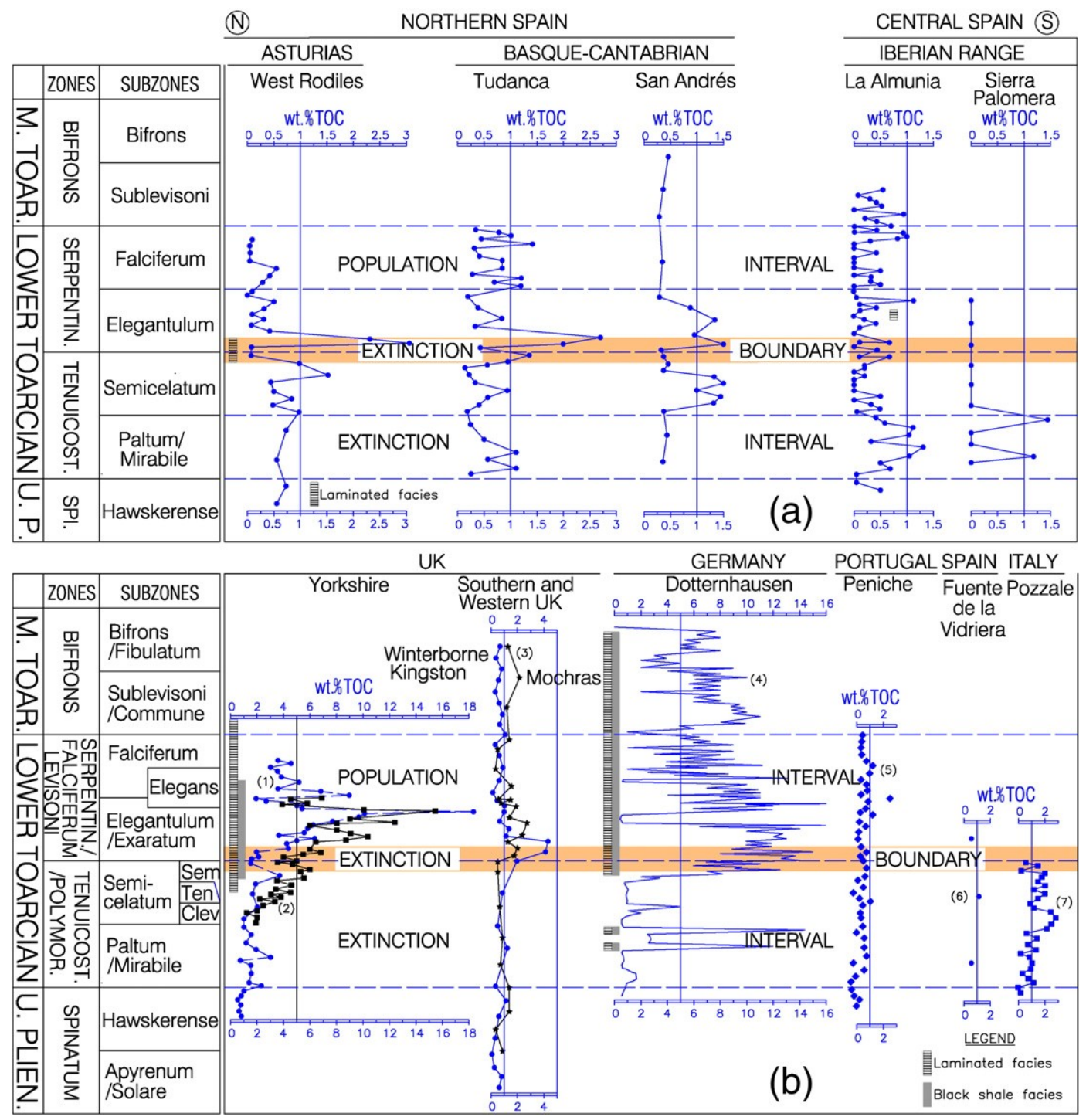

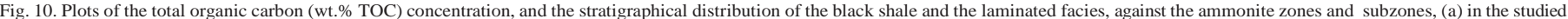

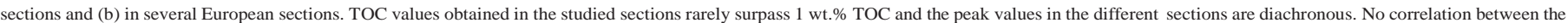

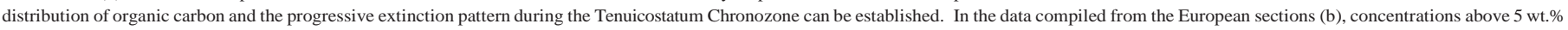

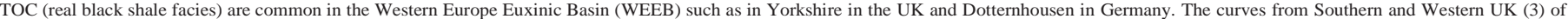

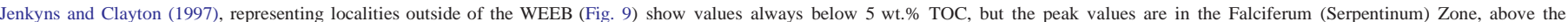

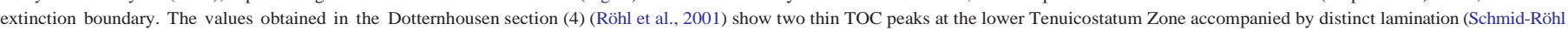

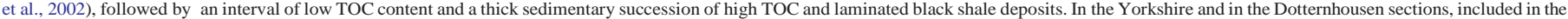

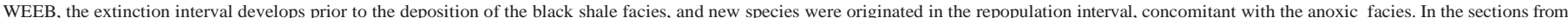

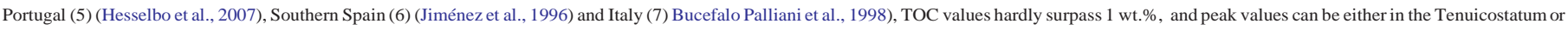
in the Serpentinum zones. In all these sections, as in most of the Spanish studied sections, the presence of bioturbated deposits, indicating well oxygenated environments, has been reported.

corroborate the virtual absence of real black shale facies outside of the WEEB. No significant laminated deposits indicating anoxic conditions have been described in the European sections. Most sediments are bioturbated (i.e. Rodríguez-Tovar and Uchman, 2010) and the benthic fauna is generally well diversified, supporting the presence of well oxygenated environments.

In Western Canada, reported TOC values between 0.3 and 1.9 wt.\% (Caruthers et al. 2010), evidence the absence of black shale facies. In the Neuquén Basin of Argentina, Al-Suwaidi et al. (2010) reported the presence of two samples surpassing 5 wt.\% TOC, and in Northern Tibet, Xia et al. (2010) reported the presence of black shale facies containing between 1.8 and 26.1 wt.\% TOC, but the Early Toarcian age of the deposits is uncertain. Data indicates that black shales have been recorded in some other basins of the World at a similar age, but in general no proofs of a generalized severe depletion of oxygen at a global scale have been found.

\subsection{Mismatch between anoxia and mass extinction}

A major point is that timing of deposition of anoxic facies in the WEEB and the presence of organic matter in the studied sections does not match with the timing of mass extinction. The extinction interval in the WEEB develops several hundred kyr before the onset of deposition of the euxinic, laminated, black shale facies, and conse- quently extinction clearly predates anoxia. That implies that, even in the area occupied by the WEEB, anoxia cannot be appointed as the main cause of mass extinction, because the progressive extinction, which marks the extinction interval, occurred much before the onset 

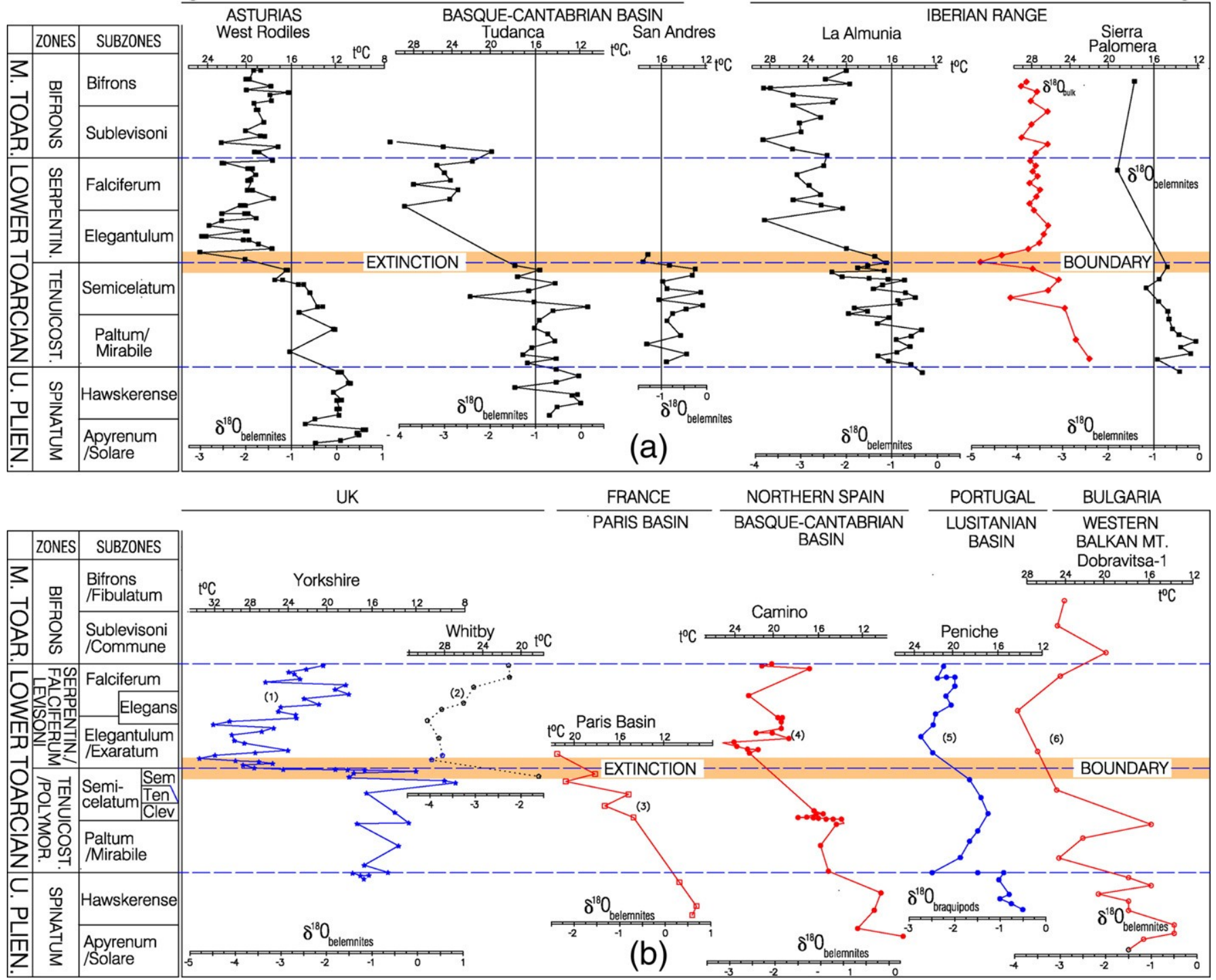

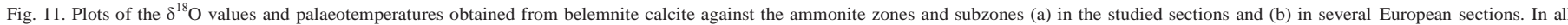

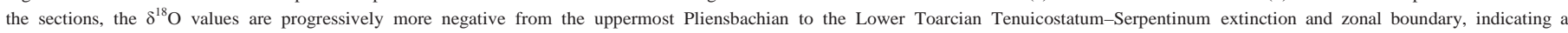

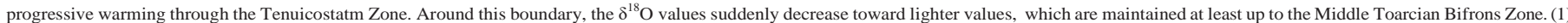

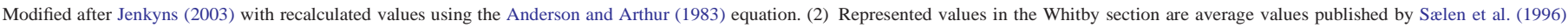
calculated for each stratigraphic interval, except for palaeotemperatures surpassing

$31{ }^{\circ} \mathrm{C}$, where salinity correction was calculated by these authors. (3) Modified after Dera et al. (2009). (4) Modified after Rosales et al. (2004). (5) Modified after Suan et al. (2008).

(6) Modified after Metodiev and Koleva-Rekalova (2008).

of the anoxic conditions. In any of the considered areas, the pattern of progressive loss of species that has been observed through the extinction interval, does not corresponds with the pattern of concomitant progressively more anoxic facies.

Anoxia could have been an important factor for regional extinction in some areas and for some other periods of time. However, it should be highlighted that in some of the sections included in the WEEB, like in the Yorkshire (Little and Benton, 1995), deposition of the anoxic laminated black shales facies was recorded during the repopulation interval, where faunas are recovering, and not during the extinction interval.

Based on the previous data, it seems clear that there is not a direct relationship in time and space between mass extinction and the presence of anoxic environments. In the Spanish Early Toarcian platform system, as well as in many other sections of Europe and northern Africa, mass extinction has also been demonstrated, but no evidences of anoxia have been found. The deposition of organic-poor facies outside of the WEBB is diachronous and generally does not coincide with extinction. All these evidences discard anoxia as the origin of the, most probably, worldwide Early Toarcian mass extinction event.

\subsection{Seawater palaeotemperature in the Spanish sections}

The use of belemnite rostra as a reliable proxy for seawater temperature reconstruction, applied in many palaeoclimatic studies, has been strongly supported by the isotopic study in seven different regions of five different species of recent cuttlefish (Sepia sp.), as cuttlebone represents the phragmocone of the belemnite shell (Rexfort and Mutterlose, 2009) and from the study of the cephalopod

S. spirula (Price et al., 2009). 
Plotting of the calculated seawater palaeotemperatures from the $\delta^{18} \mathrm{O}$ values obtained in the belemnite calcite of the studied Spanish sections (Fig. 11a), reflects the occurrence of important climate changes through the uppermost Pliensbachian and the Lower Toarcian. In the uppermost Pliensbachian, average calculated seawa- ter palaeotemperatures were about $11.6{ }^{\circ} \mathrm{C}$ in the northern sections (West Rodiles) and about $13{ }^{\circ} \mathrm{C}$ in the other sections. These temperatures can be considered as significantly low for a calculated palaeolatitude of Madrid of $30^{\circ} \mathrm{N}$ during the Toarcian, based on palaeomagnetical studies (Osete et al., 2000, 2011) (Fig. 9). Consequently, the latest Pliensbachian represents a remarkable cooling interval which can be recognized in many parts of the world (Price, 1999; Guex et al., 2001; Tremolada et al., 2005; Suan et al., 2010).

Seawater temperatures started to increase through the lowermost Toarcian Tenuicostatum Zone, where average calculated tempera- tures were in the order of $15-16{ }^{\circ} \mathrm{C}$. That represents a progressive increase on seawater temperature in the order of $3{ }^{\circ} \mathrm{C}$ respect to the calculated average temperature for the latest Pliensbachian. In the Spanish sections, comparison of the palaeotemperature with the evolution of the number of taxa reveals that progressive warming coincides first with a progressive loss in the taxa of brachiopods, and finally with the extinction of all the species of this group (García Joral et al., 2011), as well as the progressive disappearance of up to 85\% of the species of ostracods (Gómez and Arias, 2010), many species of foraminifers (Herrero, 2001) and nannofossils (Perilli, 1996a, b; 2000), marking the extinction interval (Figs. 7 and 8).

Around the Tenuicostatum-Serpentinum zonal boundary, seawa- ter palaeotemperature suddenly increased considerably, reaching values in the order of $21-23^{\circ} \mathrm{C}$. This important and rapid warming,

which represents an $\Delta \mathrm{T}$ of about $6^{\circ} \mathrm{C}$ with respect to the Tenuicos- tatum Zone, coincides with the total disappearance of the brachiopods

and the extinction of numerous species of ostracods and foraminifers. Temperatures remain high and relatively constant through the Serpentinum and Bifrons zones, but the platforms were repopulated in many cases by opportunistic immigrant species that thrived in warmer Mediterranean waters.

\subsection{Seawater palaeotemperature variations in other European sections}

Comparison between the $\delta^{18} \mathrm{O}$-derived palaeotemperature curves obtained from belemnite calcite in the Spanish sections and in other European sections, shows a close correlation in the evolution of seawater palaeotemperature across Europe (Fig. 11b). This good correlation indicates that the Early Toarcian climatechangecould probablybeglobal in extent.

Calculated average seawater palaeotemperature for Iberia in the uppermost Pliensbachian is about $13.7^{\circ} \mathrm{C}$ (Table 1), which is somewhat higher than the around $10^{\circ} \mathrm{C}$ calculated for the Paris Basin (Dera et al., 2009), and considerably lower than the $17.6^{\circ} \mathrm{C}$ calculated from the Bulgarian data (Metodiev and Koleva-Rekalova, 2008). These average temperatures can be considered lower than expected from the palaeolatitudinal position of the European and the Iberian plates at this time (Fig. 9).

Available data from other parts of the world suggest that the Late Pliensbachian represents a time of marked cooling, probably of global extent, and has been pointed out as one of the main candidates of the Mesozoic for the formation of polar ice (Price, 1999). This assumption is based on the presence of possible glendonites, supposedly of Pliensbachian age, in the Lena River (Kaplan, 1978; Rogov and Zakharov, 2010), the absence of the wood genus Xenoxylon at high latitudes (Philippe and Thevenard, 1996), and the interpretation of the Upper Pliensbachian-lowermost Toarcian hiatus in some of the European and northern African sections as due to a major shortlived regression, forced by cooling and glaciation, interpreted by Guex et al. (2001) as derived from increased volcanic activity. The general circulation model (GMC) simulation carried out by Chandler et al.
Table 1

Seawater palaeotemperatures. Statistical analysis. European sections.

\begin{tabular}{llllll}
\hline Stage & Zone & Subzone & $\begin{array}{l}\text { Mean T } \\
\left({ }^{\circ} \mathrm{C}\right)\end{array}$ & $\begin{array}{l}\text { Median T } \\
\left({ }^{\circ} \mathrm{C}\right)\end{array}$ & $\begin{array}{l}\text { Standard } \\
\text { deviation }\end{array}$ \\
\hline $\begin{array}{l}\text { Pliensbachian } \\
\text { Toarcian }\end{array}$ & Spinatum & Apyrenum & 13.7 & 13.8 & 2.3 \\
Toarcian & Tenuicostatum & Paltum & 15.1 & 15.0 & 0.9 \\
Toarcian & Senuicostatum & Semicelatum & 16.3 & 16.3 & 1.2 \\
Toarcian & Serpentinum & Elegantulum & 23.1 & 21.9 & 4.0 \\
Toarcian & Bifrons & Falciferum & 22.6 & 23.0 & 2.1 \\
\hline
\end{tabular}

(1992), concluded that winter temperatures within the continental interiors at the Early Jurassic dropped to $-31.9^{\circ} \mathrm{C}$, which is compatible with the formation of permanent or seasonal ice at

these areas of Pangea. All these data support the hypothesis that the Late Pliensbachian could represent an important cooling event of global extent.

The first step of progressive seawater warming, which can be observed in all the considered European sections, started at the Lower Toarcian Tenuicostatum Zone (Fig. 11b). The average calculated palaeotemperature in these areas is around $16{ }^{\circ} \mathrm{C}$, with a standard deviation of 1 (Table 1). These values can be considered as highly reasonable taking into account the palaeolatitudinal differences between the correlated sections. This first earliest Toarcian interval of warming, which developed through the $0.3 \mathrm{Myr}$ duration of the Tenuicostatum Zone (Ogg, 2004), represents an average $\Delta \mathrm{T}$ of about $3{ }^{\circ} \mathrm{C}$ respect to the latestPliensbachiancalculated averagepalaeotemperature.

A rapid and prominent increase in the seawater temperature was synchronously recorded in all the European sections around the Tenuicostatum-Serpentinum zonal boundary. Average temperature rose to 23 ${ }^{\circ} \mathrm{C}$ in the Serpentinum Zone (standard deviation 3), representing an average $\Delta \mathrm{T}$ of about $6-7^{\circ} \mathrm{C}$. This sudden increase in seawater temperature affected the benthic fauna but also gave rise to a pronounced crisis in the planktonic and nektonic organisms.

High seawater temperatures continued during the Middle Toarcian Bifrons Chronozone, where average temperatures of $22.5^{\circ} \mathrm{C}$ have been calculated for the considered European sections. Seawater temperatures in Spain did not return to lower values until the Middle Toarcian Variabilis Zone (Gómez et al., 2008) and further important oscillations were documented in the Upper Toarcian and in the Aalenian (Gómez et al., 2008, 2009), but they were not of the magnitude of the Early Toarcianclimatechange.

\subsection{Comparison between the fossil records and the Early Toarcian climate change}

The average values of seawater palaeotemperature obtained from belemnite calcite in the different European sections, has been plotted against the ammonite zones and subzones (Fig. 12a and b). Together with the seawater palaeotemperatures, the evolution in the number of species or the abundance and the number of First Appearances (FAs) of several groups of nektonic and planktonic organisms (Fig. 12a) and several groups of benthic organisms (Fig. 12b) from selected sections of Europe and northern Africa, has also been represented. In the areas covered by the WEEB, the stratigraphical distribution of the black shale and laminated facies, indicatives of anoxic environments, has also been plotted.

The correlation of data obtained in different sections included in the panel, evidences the relationships between the patterns of the earliest Toarcian progressive warming, and the pattern of progressive extinction, represented by the progressive loss of species during the same time interval, marking the extinction interval (Fig. 12a and b). The extinction boundary, where the extinction rates are maxima, coincides with the accelerated warming recorded at the boundary between the Tenuicostatum and the Serpentinum zones, and the 
interval located above the extinction boundary, with increasing new appearances, represents the repopulation interval.

\subsubsection{The extinction interval}

The extinction interval is represented by a progressive decrease in the number of species, concomitant with the progressive increase in seawater temperature (Fig. 12a and b). The database of ammonites from Europe and northern Morocco (Сecca and Macchioni, 2004; Bilotta et al., 2009; Dera et al., 2010) shows that a maximum in ammonites diversity was reached at the uppermost Pliensbachian, coinciding with the cooling interval, but as warming progressed through the Lower Toarcian Tenuicostatum Zone, a substantial 88\% decrease in the number of species of ammonites was recorded. At the extinction boundary, only 10 species (28\%) of the 35 present at the Pliensbachian-Toarcian boundary, survived (Cecca and Macchioni, 2004), and the ammonites species richness decreased from 70 in the uppermost Pliensbachian to less than 20 in the extinction boundary (Dera et al., 2010) (Fig. 12a). Extinction is also reflected by the ammonites of the Apennines (Italy), where from the up to 23 genera recognized in the Tenuicostatum Zone, only 7 (30\%) surpassed the extinction boundary (Bilotta et al., 2009). As expected from the nektonic organisms, with climate change, species from adjacent areas could cross frontiers and become new elements of the faunal assemblage. Due to warming, some species of ammonites tried to migrate to the cooler waters of higher latitudes, conditioning the spreading of Tethyan ammonite taxa that inhabited the Mediterra- nean warmer waters, into the colder northern European waters at the upper part of the Paltum/Mirabile Subzone. In the Yorkshire section of the UK, the number of species of belemnites also tends to decrease in the extinction interval and totally disappeared at the extinction boundary (Little and Benton, 1995), while the size of some belemnite species progressively decline (Morten and Twitchet, 2009).

Warming also affected planktonic organisms. In the Brown Moor Borehole, North Yorkshire, UK, Bucefalo Palliani et al. (2002) reported the presence of an interval of decreased pelagic carbonate production, located immediately below the extinction boundary, and an interval marking an event of disappearance of calcareous nannofossils and dinoflagellate cysts, located immediately above the extinction boundary (Fig. 12a). These two intervals are marked by a prominent decrease in the number of species of these organisms. Curiously, the same taxa of calcareous nannofossils reappear when TOC values are at a maxima. In the Dotternhausen section in Germany, a marked crisis in the dinoflagellate cysts, which temporarily disappeared, occurred in the extinction interval, predating the base of the succession enriched in organic matter (Mattioli et al., 2004) (Fig. 12a). The severe Early Toarcian biotic crisis is also reflected by the nannofossils in northern Spain. In the West Rodiles section, the abundance of Schizosphaerella sp., one of the main contributors to pelagic carbonates, and T. patulus substantially decrease and, at the extinction boundary, Calcivascularis jansae completely disappeared. On the contrary, the abundance of some other most probably opportunistic taxa, such as several species of Crepidolites, substantially increases above the extinction boundary, marking the repopulation interval (Fraguas, 2010) (Fig. 12a). Also in the Peniche section of Portugal, Suan et al. (2008) and Mattioli et al. (2009), reported a dramatic decrease in the absolute abundance of nannofossils, and a less pronounced decrease in the size of Schizosphaerella (Fig. 12a). No organic-rich deposits were found in the Portuguese section (Hesselbo et al., 2007) (Fig. 10), but the Early Toarcian warming was also measured in this area in brachiopod calcite (Suan et al., 2008, 2010). Migration toward northern cooler waters was obviously more difficult for benthic organisms, and this difficulty was enlarged by the predominant southward currents circulating through the Laurasian Seaway and the European Epicontinental Sea, as deducted from numerical palaeoceanographic modeling (Bjerrum et al., 2001) and from ostracod biogeography in NW Europe (Arias, 2006, 2007) (Fig. 9). The number of species in most of the benthic organisms tends to decreases in the UK Yorkshire section from the uppermost Pliensba- chian to the extinction boundary, and no or very few appearances of new taxa are recorded during the extinctions interval (Little and Benton, 1995). The most important reduction in the number of species in this area is recorded in the bivalves. From 13 species before the extinction interval, only 2 (15\%) survived and only a new appearance was recorded. Some species of bivalves show a significant progressive size decrease through the Tenuicostatum Zone, reaching size minimum at the Exaratum Subzone (Morten and Twitchet, 2009). Progressive loss of species was also recorded in other groups such as gastropods and brachiopods (Fig. 12b). Deposition of laminated black shale facies in this region, indicating euxinic conditions, started at the uppermost Semicelatum Subzone (Hesselbo and Jenkyns, 1995), slightly below the extinction boundary. However, progressive disappearance of numerous taxa occurs about 0.3 Myr before the onset of deposition of these black shale laminated facies, but concomitant with the progressive increase of seawater temperature. The extinction interval is also well marked by the benthic organisms in the Spanish sections (Fig. 12b), as described in section 4. One of the most spectacular cases of extreme extinction has been reported by Bassoullet et al. (1991) in the Moulay-Idriss section of the Middle Atlas in Morocco, where only 4 species over 36 of benthic

foraminifers, surpassed the extinction boundary (Fig. 12b).

Data from North Siberia and the Arctic Region also indicate the record of the Early Toarcian mass extinction in these regions. Zakharov et al. (2006) report a significant reduction in the number of taxa and a complete renewal of genera and families of bivalves, ostracods, foraminifers, dinocysts, spores and pollen at the base of the Falciferum Zone. These authors link the biotic turnover mainly with thermal changes and climatic fluctuations. Nikitenko (2008) men- tions the disappearance of the last representatives of the Pliensba- chian foraminifers and ostracods in the upper Antiquum-lower Falciferum ammonites zones, equivalent to the Western Europe Tenuicostatum-Serpentinum zonal boundary, and a later nearly complete taxonomic renewal of these groups, supporting the global

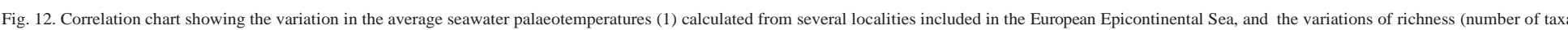

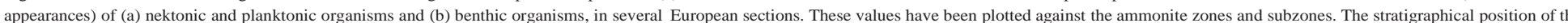

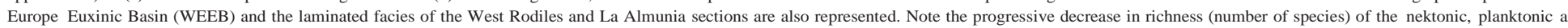

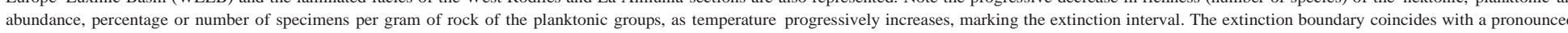

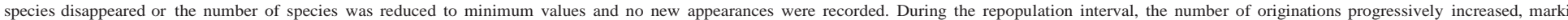

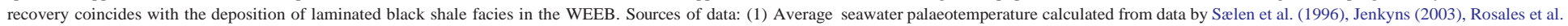

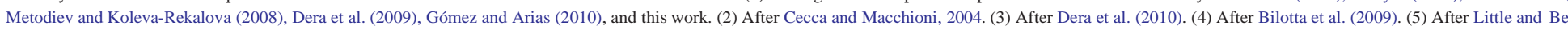
After Bucefalo Palliani et al. (2002). (7) After Mattioli et al. (2004). (8) After Fraguas (2010). (9) After Suan et al. (2008). (10) After

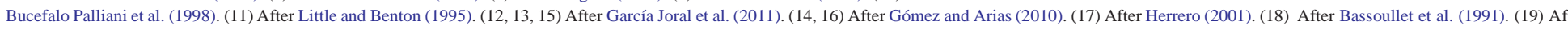



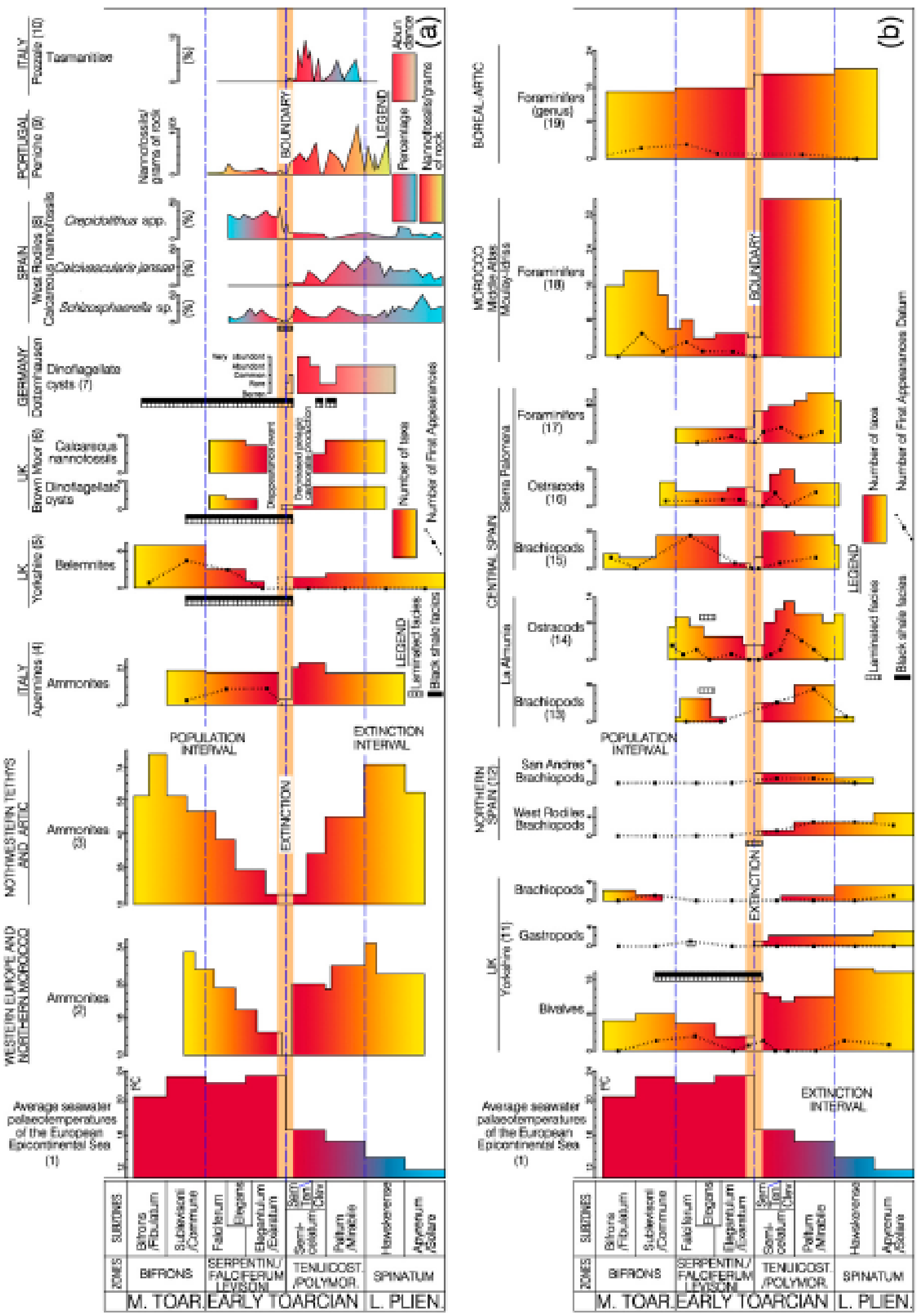
extent of the Early Toarcian biotic crisis, concomitant with the warming episode.

\subsubsection{The extinction boundary}

The extinction boundary is well marked in all the studied and referenced sections around the Tenuicostatum-Serpentinum zonal boundary, coinciding with the sudden and major increase in seawater temperature. No FAs in virtually any of the fossil groups of the considered sections were reported at that time. Ammonites recorded a minimum value in the number of species around this boundary in Europe, Northern Africa and the Mediterranean. At the Yorkshire (UK), bivalves experienced a drastic reduction in the number of species, and gastropods, brachiopods, and belemnites seem to disappear (Little and Benton, 1995). Representatives of some planktonic groups such as dinoflagellate cysts and calcareous nannofossils temporarily or completely disappear around the extinction boundary, whether before the onset of deposition of black shale facies, in the WEEB, or in other areas of Europe with no indications of anoxia.

In Asturias and in the Basque-Cantabrian Basin of Northern Spain, brachiopods completely become extinct and, as in many parts of Western Europe, they did not recover until Middle Toarcian. Brachiopods also disappeared in the sections of central Spain, where no indications of significant oxygen depletion can be observed. The Early Toarcian mass extinction was especially dramatic for the brachiopods, representing the most important turnover events for this group during the Mesozoic and the Cenozoic periods. Two of the 7 orders, the Spiriferinida and the Athyrida orders, and 5 of the 12 superfamilies that were represented before the extinction boundary, disappeared. Around $70 \%$ of the genera of the order Rhynchonellida left and an important renewal of the order Terebratulida occurred (García Joral et al., 2011). Ostracods and foraminifers also suffered a very significant reduction in their diversity. In the extreme case of Morocco, only $11 \%$ of the species of foraminifers surpassed the synchronous extinction boundary (Bassoullet et al., 1991). While data from Zakharov et al. (2006) show that the main crisis for some organisms correspond to the Pliensbachian-Toarcian transition, some data from North Siberia and the Arctic Region locates a "crisis of the

benthic communities" within the Antiquum Zone $(\approx$ Tenuicostatum Zone) (Nikitenko, 2008) which can be correlated with the Western Europe extinction boundary.

The lack of evidences of anoxia in the European sections, outside of the WEEB, and in Northern Morocco, together with the evidence of increased seawater temperature concomitant with extinction, points once more to warming as the main cause of the Early Toarcian mass extinction.

\subsubsection{The repopulation interval}

Repopulation of the Early Toarcian marine platforms was unequal for the different groups. Ammonites diversity rapidly increased, and by the Middle Toarcian Bifrons Zone, the number of species even surpassed the preextinction values in some areas. That was due in part to the expansion to the north of some typically Mediterranean groups inhabiting warm waters, favored by the increase of seawater temperature in the European Epicontinental Sea.

In spite of the anoxic conditions installed in the WEEB, bivalves recorded the appearance of new taxa and progressively increased the number of species in the Yorkshire area (UK), marking the repopula- tion of the platform by benthic faunas (Little and Benton, 1995). Gastropods apparently did not recover so well and brachiopods, as in many areas of Western Europe and in Northern Spain, did not recover until the Middle Toarcian. That represents a period of about $2 \mathrm{Myr}$ without representatives of brachiopods in the West European platforms. Belemnites recovered and in the Bifrons Zone the number of species surpassed the number of species recorded in the extinction interval, and some of the species show significant increase in guard diameter through the recovery interval (Morten and Twitchet, 2009).
After the temporal disappearance of dinoflagellate cysts and calcar- eous nannofossils, marking the decreased pelagic carbonate produc- tion and the disappearance event, both groups recovered, but some species were lost.

The occurrence at Dotternhausen of four stratigraphic intervals with abundant specimens of bivalves was interpreted by Röhl et al. (2001) and Schmid-Rhöl et al. (2002) as interruptions of the anoxic bottom waters conditions by short oxygenated periods allowing the development of occasional populations of bivalves.

Recovery of most of the groups was relatively rapid in the well oxygenated environments of central Spain. After the total extinction of the brachiopods, the Spanish platforms were colonized in about

$0.5 \mathrm{Myr}$ by an opportunistic species of brachiopod, probably derived from Tethyan species better adapted to warmer environments. Ostracods also recovered; even during the Serpentinum Zone they did not reach the degree of pre-extinction diversity. Similar recovery pattern is shown by the Moroccan foraminifers. After the extinction boundary new species appeared, but the total number of species in most groups during the Middle Toarcian did not reach the degree of diversity recorded at the lowermost Toarcian.

\subsection{Possible mechanisms of mass extinction}

The rapid climate change and the mass extinction event that occurred during the Early Toarcian, offers excellent opportunities to analyze the possible links between the patterns of the past climate changes and the patterns of the floral and faunal mass extinctions (e.g. Courtillot and Gaudemer, 1996; Culver and Rawson, 2000; Benton and Twitchett, 2003; Twitchett, 2006; Mayhew et al., 2008; Gómez et al., 2008, 2009). This analysis also allows evaluating the time interval needed for the different components of the faunal assemblages to recover the pre-extinction degree of diversity.

Studies focussed on the past and current global warming intervals and the concomitant biotic crisis in the oceans can be applied to speculate on the possible mechanisms that conducted to the Early Toarcian mass extinction. Analysis of the possible causes of the big five mass extinction events led Twitchett (2006) to conclude that all these events are associated with evidence of climatic change. According to this author, environmental consequences of rapid global warming have been particularly detrimental to the biosphere.

On the other hand, observed biotic responses to warming in current oceans are providing mechanisms by which climate change affects individual physiology, seasonal timing, phenology of organ- isms, composition and dynamics of populations and geographic distribution (Walther et al., 2002). One of the most evident impacts of warming is the thermal stress that many organisms suffer when their physiological upper thermal limit is surpassed. There is an optimum temperature range for skeletal secretion, biochemical and physiological activity and growth, but there are limits which the effect of temperature is lethal (Twitchett, 2006). If thermal tolerance is exceeded, physiological dysfunctions appear, conducting organisms to subsequent mortality. One of the current examples is the death of the $16 \%$ of the world reef-building corals in 1998, a year when sea temperatures exceeded longterm averages (Walther et al., 2002).

Another important effect is that warming causes a density contrast and hence notable seawater stratification between the surface layer and the underlying waters, which are rich in nutrients. As a consequence, enhanced seawater stratification suppresses nutrients exchange through vertical mixing, and the phytoplankton net primary productivity, which roughly represents half of the net primary production of the biosphere, in current and probably in past oceans, strongly decreases (Behrenfeld et al., 2006). Suppression of nutrients transports to the planktonic organisms living in the upper layer of the oceans, dramatically alters the availability of the marine food, affecting the primary and secondary production (Walther et al., 2002) and hence increasing the warming-driven mass mortality 
(Coma et al., 2009). The severe warming also conditions more slow oceanic circulation, reducing upwelling, which conduct to a global decrease in primary productivity (Kidder and Worsley, 2004; Twitchett, 2006). Indications on this effect are provided by the warming after the last Ice Age, when surface productivity in the oceans declined by $50 \%$ (Herguera and Berger, 1991, 1994).

Phenologic processes, which are related to the annually recurring life cycles, particularly affects to marine environments, because of the life of higher trophic levels depends on the synchronization with pulsed planktonic production. The mismatch between successive trophic levels and a change in the synchrony between primary producers and the components of the other trophic levels (Edwards and Richardson, 2004) is conducting to a notable biotic crisis in currentoceans.

From current experience, it seems clear that warming can be a direct or indirect responsible of mass extinctions. Warming can induce severe decreases in the availability of nutrients for phyto- plankton growth, breaking the trophic net, reducing the ocean productivity and conducting to mass mortality. Warming also produces significant losses and fragmentations of habitats. Areas that were climatically suitable for some organisms were distant from their area of distribution and palaeoceanographical conditions do not allow migration to these areas. That is probably the case for many of the Early Toarcian benthic organisms living in the European Epicontinental Sea, that were not able to migrate northward, to cooler environments, due to the predominant southward currents in the Laurasian Seaway and the European Epicontinental Sea. Species with low adaptability and/or low dispersal capacity were trapped by the climate-forced change and the low probability to arrive to distant habitats to colonize, resulting in dramatically increased extinction rates and decrease of origination rates.

\section{Conclusions}

Comparison between the patterns of the Early Toarcian progres- sive warming and the concomitant progressive loss of species, conducting to mass extinction, evidences a cause-and-effect relation- ship between the increase of temperature and the severe biotic crisis. The first step of warming, which started at the onset of the Lower

Toarcian Tenuicostatum Zone, represents a progressive $\Delta \mathrm{T}$ of about $3{ }^{\circ} \mathrm{C}$ respect to the average palaeotemperature of the latest Pliensba-

chian cooling event. Increasing temperature is associated with a progressive and substantial lose in the number of species of nektonic, planktonic and benthic organisms, representing the extinction interval. Migration of the benthic organisms towards northern cooler waters was impeded by the predominant southward currents circulating through the Laurasian Seaway and the European Epicon- tinental Sea.

A rapid and prominent increase in seawater temperature occurred around the Tenuicostatum-Serpentinum zonal boundary. Average temperatures at the Serpentinum Zone represented an average $\Delta \mathrm{T}$ of about $6-7^{\circ} \mathrm{C}$. This sharply accelerated increase in seawater temper- ature marks the maxima extinction rates that define the extinction

boundary. Diversity substantially decreased in all the fossil groups and no FAs in virtually any of the fossil groups occurred.

The high seawater temperature continued during the Bifrons Chronozone, where average temperatures of $22.5{ }^{\circ} \mathrm{C}$ have been calculated for the European sections. The number of taxa as well as the number of new appearances increased, representing the repopu- lation interval.

Anoxia linked to the postulated Early Toarcian Oceanic Anoxic Event (ETOAE) cannot be the responsible of mass extinction, because mass extinction occurs synchronously in the well oxygenated environments of the European and Northern African platforms, where no indications of anoxic environments were observed. Deposition of laminated organic-rich black shale facies indicating euxinic environments was nearly exclusively confined to the WEEB and mainly developed during the recovery interval, postdating the extinction interval.

Current and past evidences indicate that warming can be a direct or indirect responsible of mass extinctions. Some of the most evident impacts of warming in marine faunal and floral assemblages are the thermal stress, the decrease of phytoplankton net primary produc- tivity, the phenologic processes, the losses and fragmentations of habitats, and the loss of species with low adaptability and/or low dispersal capacity.

\section{Acknowledgments}

We gratefully acknowledge F. Surlyk and two anonymous re- viewers for valuable comments and constructive reviews. This research work was financed by projects CGL 2008-03112 and CGL 2008-01273 of the Spanish Ministerio de Educación y Ciencia, and by projects GR58/08B/910431, GR58/08A/910429 and GR58/08A/91039 of the Universidad Complutense de Madrid. Thanks to the Instituto Geologico y Minero de España for allowing the use of the cathodoluminiscence microscope.

\section{References}

Aberhan, M., Baumiller, T.K., 2003. Selective extinction among Early Jurassic bivalves: a consequence of anoxia. Geology 31, 1077-1080.

Aberhan, M., Fürsich, F.T., 1997. Diversity analysis of Lower Jurassic bivalves of the Andean Basin and the Pliensbachian-Toarcian mass extinction. Lethaia 29, 181-195.

Almeras, Y., Fauré, P., 1990. Histoire des brachiopodes liasiques dans la Téthys occidentale: les crises et l'écologie. Cahiers Univ. Catho. Lyon, sér. Sci 4, 1-12.

Al-Suwaidi, A.H., Angelozzi, G.N., Baudin, F., Damborenea, S.E., Hesselbo, S.P., Jenkyns, H.C., Manceñido, M.O., Riccardi, A.C., 2010. First record of the Early Toarcian Oceanic Anoxic Event from the Southern Hemisphere, Neuquén Basin. Argentina.

J. Geol. Soc. London 167, 633-636.

Anderson, T.F., Arthur, M.A., 1983. Stable isotopes of oxygen and carbon and their application to sedimentologic and paleoenvironmental problems. In: Arthur, M.A. (Ed.), Stable Isotopes in Sedimentary Geology: SEPM Short Course, 10, pp. 1-1$1-151$.

Arias, C.F., 1996a. Ostracods. In: Ureta, S. (Ed.), The Toarcian in the Sector Located between La Almunia de Doña Godina and Ricla. 1st Toarcian and 4th Aalenian Working Groups Meeting. Fieldtrip Iberian Range, pp. 18-20.

Arias, C.F., 1996b. Ostracods. In: Ureta, S. (Ed.), The Toarcian in the Rambla del Salto (Sierra Palomera) section. 1st Toarcian and 4th Aalenian Working Groups Meeting. Fieldtrip Iberian Range, pp. 42-44.

Arias, C., 1997. Ostracod biostratigraphy of the Lower Toarcian in the Cordillera Iberica, North-East Spain. Neues Jb. Geol. Paläontol. Abh. 206, 67-91.

Arias, C., 2006. Northern and Southern Hemisphere ostracod palaeobiogeography during the Early Jurassic: possible migration routes. Palaeogeogr. Palaeoclimatol. Palaeoecol. 233, 6395

Arias, C., 2007. Pliensbachian-Toarcian ostracod biogeography in NW Europe: evidence for water mass structure evolution. Palaeogeogr. Palaeoclimatol. Palaeoecol. 251, 398-421.

Arias, C.F., Comas-Rengifo, M.J., Goy, A., Herrero, C., Ruget, C., 1992. Variations dans les associations de brachiopodes, foraminifères et ostracodes du Toarcien basal dans un secteur central de la Cordillère Ibérique. Un example dans la "Rambla del Salto" (Teruel, Espagne). Sci $5,5-25$.

Bassoullet, J.P., Baudin, F., 1994. Le Toarcien inférieur: une période de crise dans les bassins et sur les plate-formes carbonatées de l'Europe du Nord-Ouest et de la Téthys. Geobios 17, 645-654.

Bassoullet, J.P., Lachkar, G., Baudin, F., Benshili, K., Blanc, P., Boutakiout, M., Depêche, F., Elmi, S., Ruget, C., 1991. Stratigraphie intégrée dans le Toarcien du Maroc (rides sud-rifaines et Moyen Atlas). Bull. Soc. Geól. Fr. 162, 825-839.

Glossary of Geology. In: Bates, R.L., Jackson, J.A. (Eds.), A. Geol. Inst, Alexandria, Virginia, USA

Behrenfeld, M.J., O'Malley, R.T., Siegel, D.A., McClain, C.R., Sarmiento, J.L., Feldman, G.C., Milligan, A.J., Falkowski, P.G., Letelier, R.M., Boss, E.S., 2006. Climate-driven trends in contemporary ocean productivity. Nature $444,752-755$.

Benton, M.J., Twitchett, R.J., 2003. How to kill (almost) all life: the end-Permian extinction event. Trends Ecol. Evol. 18, 358-365.

Bernad, J., 1996a. Bivalves. In: Ureta, S. (Ed.), The Toarcian in the Sector Located between La Almunia de Doña Godina and Ricla. 1st Toarcian and 4th Aalenian Working Groups Meeting. Fieldtrip Iberian Range, pp. 14-15.

Bernad, J., 1996b. Bivalves. In: Ureta, S. (Ed.), The Toarcian in the Rambla del Salto Section (Sierra Palomera). 1st Toarcian and 4th Aalenian Working Groups Meeting. Fieldtrip Iberian Range, pp. 36-40.

Bilotta, M., Venturi, F., Sassaroli, S., 2009. Ammonite faunas, OAE and the Pliensbachian- Toarcian boundary (Early Jurassic) in the Apenines. Lathaia. doi:10.1111/j.1502- 3931.2009.00201. 
Bjerrum, C.J., Surlyk, F., Callomon, J.H., Slingerland, R.L., 2001. Numerical paleoceano- graphic study of the Early Jurassic Transcontinental Laurasian Seaway. Paleocea- nography 16, 390404

Bodin, S., Mattioli, E., Fröhlich, S., Marshall, J.D., Boutib, L., Lahsini, S., Redfern, J., 2010. Toarcian carbon isotope shifts and nutrient changes from the Northern margin of Gondwana (High Atlas, Morocco, Jurassic): palaeoenvironmental implications. Palaeogeogr. Palaeoclimatol. Palaeoecol. 297, 377-390.

Bucefalo Palliani, R., Cirilli, S., Mattioli, E., 1998. Phytoplankton response and geochemical evidence of the lower Toarcian relative sea level rise in the Umbria- Marche basin (Central Italy). Palaeogeogr. Palaeoclimatol. Palaeoecol. 142, 33-50. Bucefalo Palliani, R., Mattioli, E., Riding, J.B., 2002. The response of marine phytoplankton and sedimentary organic matter to the early Toarcian (Lower Jurassic) oceanic anoxic event in northern England. Mar. Micropaleontol. 46, 223-245.

Caruthers, A.H., Gröcke, D.R., Smith, P.L., 2010. The Early Toarcian oceanic anoxic event in Western Canada. Earth Sci. Frontiers 17, 338-339 Special Issue.

Cecca, F., Macchioni, F., 2004. The two Early Toarcian (Early Jurassic) extinction events in ammonoids. Lethaia 37, 35-56.

Chandler, M.A., Rind, D., Ruedy, R., 1992. Pangaean climate during the Early Jurassic: GCM simulations and the sedimentary record of paleoclimate. Geol. Soc. Am. Bull. 104, 543-559.

Coma, R., Ribes, M., Serrano, E., Jiménez, E., Salat, J., Pascual, J., 2009. Global warming- enhanced stratification and mass mortality events in the Mediterranean. www. pnas.org/cgi/doi/10.1073/pnas.0805801106.

Comas-Rengifo, M.J., Gómez, J.J., Goy, A., Arias, C.F., Bernad, J., García Joral, F., Herrero, C., Martínez, G., Perilli, N., 1996. The Toarcian in the Rambla del Salto (Sierra Palomera) section. In: Ureta, S. (Ed.), 1st Toarcian and 4th Aalenian Working Groups Meeting. Fieldtrip Iberian Range, pp. $27-48$.

Courtillot, V., Gaudemer, Y., 1996. Effects of mass extinction on biodiversity. Nature 381, 146-148.

Culver, S.J., Rawson, P.F. (Eds.), 2000. Biotic Response to Global Change: The Last 145 Million Years. Cambridge University Press, UK.

Dera, G., Pucéat, E., Pellenard, P., Neige, P., Delsate, D., Joachimski, M.M., Reisberg, L., Martinez, M., 2009. Water mass exchange and variations in seawater temper- ature in the NW Tethys during the Early Jurassic: evidence from neodymium and oxygen isotopes of fish teeth and belemnites. Earth Planet. Sci. Lett. 286, 198-207.

Dera, G., Neige, P., Dommergues, J.L., Fara, E., Lafont, R., Pellenard, P., 2010. High- resolution dynamics of Early Jurassic marine extinctions: the case of Pliensbachian- Toarcian ammonites (Cephalopoda). J. Geol. Soc. London 167, 21-33.

Dera, G., Brigaud, B., Monna, F., Laffont, R., Pucéat, E., Decpnincl, J.F., Pellenard, P., Jpachimski, M.M., Durlet, C., 2011. Climatic ups and downs in a disturbed Jurassic world. Geology 39, 215-218.

Edwards, M., Richardson, A.J., 2004. Impact of climate change on marine pelagic phenology and trophic mismatch. Nature 430, 881-884.

Fraguas, A. 2010. Late Sinemurian-Early Toarcian calcareous nannofosils from the Cantabrian Basin: spatial and temporal distribution. Ph. D. thesis, Fac. Sci. Geol. Univ. Complutense Madrid.

Gahr, M.E., 2005. Response of Lower Toarcian (Lower Jurassic) macrobenthos of the Iberian Peninsula to sea level changes and mass extinction. J. Iberian Geol. 31, 197-215.

García Joral, F., Goy, A., 1996. Brachiopods. In: Ureta, S. (Ed.), The Toarcian in the Sector Located between La Almunia de Doña Godina and Ricla. 1st Toarcian and 4th Aalenian Working Groups Meeting. Fieldtrip Iberian Range, pp. 12-14.

García Joral, F., Gómez, J.J., Goy, A., 2011. Mass extinction and recovery of the Early Toarcian (Early Jurassic) brachiopods linked to climate change in northern and central Spain. Palaeogeogr. Palaeoclimatol. Palaeoecol. 302, 367-380.

Golonka, J., 2006. Late Triassic and Early Jurassic palaeogeography of the World. Palaeogeogr. Palaeoclimatol. Palaeoecol. 244, 297-307.

Gómez, J.J., Arias, C., 2010. Rapid warming and ostracods mass extinction at the Lower Toarcian (Jurassic) of central Spain. Mar. Micropaleontol. 74, 119-135.

Gómez, J.J., Goy, A., 2010. Early Toarcian (Early Jurassic) mass extinction linked to warming in northern and central Spain. Comparison with other sections of Western Europe. Earth Sci. Frontiers Spec. Publ. 17, 374-375.

Gómez, J.J., Goy, A., Canales, M.L., 2008. Seawater temperature and carbon isotope variations in belemnites linked to mass extinction during the Toarcian (Early Jurassic) in Central and Northern Spain. Comparison with other European sections. Palaeogeogr. Palaeoclimatol. Palaeoecol. 258, 28-58.

Gómez, J.J., Canales, M.L., Ureta, S., Goy, A., 2009. Palaeoclimatic and biotic changes during the Aalenian (Middle Jurassic) at the southern Laurasian Seaway (Basque-Cantabrian Basin, northern Spain). Palaeogeogr. Palaeoclimatol. Palaeoecol. 275, 14-27.

Goy, A., Martínez, G., 1990. Biozonación del Toarciense en el área de La Almunia de Doña Godina-Ricla (Sector Central de la Cordillera Ibérica). Cuad. Geol. Ibérica 14, 11-53.

Goy, A., Martínez, G., Ureta, S., 1994. El Toarciense en la región de Pozazal-Reinosa (Cordillera Cantábrica, España). Col. Paleontol. 46, 93-127.

Goy, A., Martínez, G., Arias, C., Bernad, J., Garcia-Joral, F., Gómez, J.J., Herrero, C., Perilli, N., Ureta, S., 1996. The Toarcian in the sector located between La Almunia de Doña Godina and Ricla. In Ureta, S. (Ed.), 1st Toarcian and 4th Aalenian Working Groups Meeting. FieldTrip Iberian Range Guide-Book. Department of Paleontology Universidad Complutense de Madrid, pp. 3-23.

Goy, A., Gómez, J.J., Herrero, C., Suárez-Vega, L.C., 1997. El Toarciense inferior en el sector comprendido entre Rodiles y Lastres (Asturias). 4th Congr. Jurásico España. Alcañiz, Zaragoza, España, pp. 81-82.

Goy, A., Comas-Rengifo, M.J., García-Ramos, J.C., Gómez, J.J., Herrero, C., Suárez-Vega, L.C., Ureta, M., 2010. The Toarcian Stage in Asturias (North Spain): amonite record, stratigraphy and correlations. Earth Sci. Frontiers Spec. Publ. 17, 38-39.
Guex, J., Morard, A., Bartolini, A., Morettini, E., 2001. Découverte d'une importante lacune stratigraphique à la limite Domérien-Toarcien: implications paléo- océnographiques. Bull. Soc. Vaud. Sc. Nat. $87,277-284$.

Hallam, A., 1986. The Pliensbachian and Tithonian extinction events. Nature 319, 765-768.

Hallam, A., 1987. Radiations and extinctions in relation to environmental change in the marine Jurassic of North West Europe. Paleobiol 13, 152-168.

Hallam, A., 1996. Major bio-events in the Triassic and Jurassic. In: Walliser, O.H. (Ed.), Global Events and Event Stratigraphy in the Phanerozoic. Springer-Verlag, pp. 265-283.

Harries, P.J., Little, C.T.S., 1999. The Early Toarcian (Early Jurassic) and the Cenomanian- Turonian (Late Cretaceous) mass extinctions: similarities and contrasts. Palaeo- geogr. Palaeoclimatol. Palaeoecol. 154, 39-66.

Hart, M.B., Hylton, M.D., Smart, C.W., 2010. Foraminiferal response to the Toarcian extinction event. Earth Sci. Frontiers. Spec. Publ. 17, 369-370.

Herguera, J.C., Berger, W.H., 1991. Paleoproductivity from benthic foraminiferal abundance glacial to postglacial change in the western Equatorial Pacific. Geology 19, 1173-1176.

Herguera, J.C., Berger, W.H., 1994. Glacial to post-glacial drop in productivity in the western Equatorial Pacific - mixing rate vs nutrient concentrations. Geology 22, 629-632.

Herrero, C., 1993. Los foraminíferos del Toarciense inferior de la Cordillera Ibérica. Colección Tesis Doctorales, 87/93. Ed. Universidad Complutense de Madrid.

Herrero, C., 1996. Foraminifera. In: Ureta, S. (Ed.), The Toarcian in the Sector Located between La Almunia de Doña Godina and Ricla. 1st Toarcian and 4th Aalenian Working Groups Meeting. Fieldtrip Iberian Range, pp. 16-18.

Herrero, C., 2001. Foraminíferos del Toarciense en la Rambla del Salto (Sierra Palomera, Teruel, España): distribución estratigráfica y principales eventos. Rev. Esp. Micropaleontol. 33, 79-89.

Hesselbo, S.P., Jenkyns, H.C., 1995. A comparison of the Hettangian to Bajocian successions of Dorset and Yorkshire. In: Taylor, P.D. (Ed.), Fied Geology of the British Jurassic. Geol. Soc London, pp. 105-150.

Hesselbo, S.P., Gröcke, D.R., Jenkyns, H.C., Bjerrum, C.J., Farrimond, P., Morgans Bell, H.S., Green, O.R. 2000. Massive dissociation of gas hydrate during a Jurassic oceanic anoxic event. Nature 406, 392-395.

Hesselbo, S.P., Jenkyns, H.C., Duarte, L.V., Oliveira, L.C.V., 2007. Carbon-isotope record of the Early Jurassic (Toarcian) Oceanic Anoxic Event from fossil wood and marine carbonate (Lusitanian Basin, Portugal). Earth Planet. Sci. Lett. 253, 455-470.

Hylton, M.D., Hart, M.B., 2000. Benthic foraminiferal response to Pliensbachian- Toarcian (Lower Jurassic) sea-level change and oceanic anoxia in NW Europe. GeoResearch Forum 6, 455-462.

Jenkyns, H.C., 1988. The early Toarcian (Jurassic) anoxic event: stratigraphic, sedimentary and geochemical evidence. Am. J. Sci. 288, 101-151.

Jenkyns, H.C., 2003. Evidence for rapid climate change in the Mesozoic-Palaeogene greenhouse world. Phil. Trans. Roy. Soc. Lond. A 361, 1885-1916.

Jenkyns, H.C., Clayton, C.J., 1986. Black shales and carbon isotopes in pelagic sediments from the Tethyan Lower Jurassic. Sedimentology 33, 87-106.

Jenkyns, H.C., Clayton, C.J., 1997. Lower Jurassic epicontinental carbonates and mudstones from England and Wales: chemostratigraphic signals and the early Toarcian anoxic event. Sedimentology 44, 687-706.

Jenkyns, H.C., Jones, C.E., Gröcke, D.R., Hesselbo, S.P., Parkinson, D.N., 2002 Chemostratigraphy of the Jurassic System: application, limitations and implications for palaeoceanography. J. Geol. Soc. London 159, 351-378.

Jiménez, A.P., Jiménez de Cisneros, C., Rivas, P., Vera, J.A., 1996. The Early Toarcian Anoxic Event in the Westernmost Tethys (Subbetic): paleogeographic and paleobiogeographic significance. J. Geol. 104, 399-416.

Joral, F.G., Goy, A., 2000. Stratigraphic distribution of Toarcian brachiopods from the Iberian Range(Spain) and its relation to depositional sequences. GeoResearch Forum 6, 381-386.

Kaplan, M.E., 1978. Calcite pseudomorphoses in Jurassic and Coger Cretaceous deposits of the Northern Area of Eastern Siberia. Geol. Geofiz. 19, 62-70.

Kauffman, E.G., Erwin, D.H., 1995. Surviving mass extinctions. Geotimes 14, 14-17. Kearey, P.

2001. The New Penguin Dictionary of Geology. Penguin, London.

Kemp, A.E.S., 1996. Laminated sediments as paleo-indicators. In: Kemp, A.E.S. (Ed.) Palaeoclimatology and Palaeoceanography from Laminated Sediments: Geol. Soc. Spec. Publ, 116, pp. vii-xii.

Kemp, D.B., Coe, A.L., Cohen, A.S., Schwark, L., 2006. Palaeoceanography: methane release in the Early Jurassic period (Reply). Nature 441, E5-E6.

Kidder, D.L., Worsley, D.R., 2004. Causes and consequences of extreme Permo-Triassic warming to globally equable climate and relation Permo-Triassic extinction and recovery. Palaeogeogr. Palaeoclimatol. Palaeoecol. 203, 207-237.

Little, C.T.S., Benton, M.J., 1995. Early Jurassic mass extinction: a global long-term event. Geology 23, 495-498.

Macchioni, F., 2002. Myths and legends in the correlation between the Boreal and Tethyan Realms. Implications on the dating of the Early Toarcian mass extinction and the Oceanic Anoxic Event. Geobios Mém. Spec. 35, 150-164.

Macchioni, F., Cecca, F., 2002. Biodiversity and biogeography of middle-late Liassic ammonoids: implications for the early Toarcian mass extinction. Geobios Mém. Spec. 24, $165-175$.

Mailliot, S., Mattioli, E., Guex, J., Pittet, B., 2006. The Early Toarcian anoxia, a synchronous event in the Western Tethys? An approach by quantitative biochronology (Unitary Associations), applied on calcareous nannofossils. Palaeo- geogr. Palaeoclimatol. Palaeoecol. 240, 562-586.

Mailliot, S., Mattioli, E., Bartolini, A., Baudin, F., Pittet, B., Guex, J., 2009. Late Pliensbachian-Early Toarcian (Early Jurassic) environmental changes in an epicontinental basin of NW Europe (Causses area central France): a micropale- ontological and geochemical approach. Palaeogeogr. Palaeoclimatol. Palaeoecol. 273, 346-364. 
Mattioli, E., Pittet, B., Bucefalo Palliani, R., Röhl, H.J., Schmid-Röhl, A., Morettini, E., 2004 Phytoplankton evidence for the timing and correlation of palaeoceanographical changes during the early Toarcian oceanic anoxic event (Early Jurassic). J. Geol. Soc. London 161，685-693.

Mattioli, E., Pittet, B., Pettpierre, L., Mailliot, S., 2009. Dramatic decrease of palagic carbonate production by nannoplanton across the Early Toarcian anoxic event (T-OAE). Global Planet. Change 65, 134-145.

Mayhew, P.J., Jenkins, G.B., Benton, T.G., 2008. A long-term association between global temperature and biodiversity, origination and extinction in the fossil record. Proc. Roy. Soc. B 275, 47-53.

McArthur, J.M., 2007. Comment on "Carbon-isotope record of the Early Jurassic (Toarcian) Oceanic Anoxic Event from fossil wood and marine carbonate (Lusitanian Basin, Portugal)". In: Hesselbo, S.P., Jenkyns, H.C., Duarte, L.V., Oliveira, L.C.V. (Eds.), Earth Planet. Sci. Let., 259, pp. 634-639.

McArthur, J.M., Donovan, D.T., Thirlwall, M.F., Fouke, B.W., Mattey, D., 2000. Strontium isotope profile of the early Toarcian (Jurassic) oceanic anoxic event, the duration of ammonite biozones, and belemnite palaeotemperatures. Earth Planet. Sci. Lett. 179, 269-285.

McArthur, J.M., Doyle, P., Leng, M.J., Reeves, K., Williams, T., García-Sanchez, R., Howart, R.J., 2007. Testing palaeo-environmental proxies in Jurassic belemnites: $\mathrm{Mg} / \mathrm{Ca}, \mathrm{Sr} / \mathrm{Ca}, \mathrm{Na} / \mathrm{Ca}, \delta^{18} \mathrm{O}$ and $\delta^{13}$ C. Palaeogeogr. Palaeoclimatol. Palaeoecol. 252, 464-480.

McArthur, J.M., Algeo, T.J., van de Schootbrugge, B., Li, Q., Howart, R.J., 2008. Basinal restriction, black shales, Re-Os dating, and Early Toarcian (Jurassic) oceanic anoxic event. Paleoceanography 23, Pa4217. doi:10.1092/2008PA001607.

Metodiev, L., Koleva-Rekalova, E., 2008. Stable isotope records $\left(\delta^{18} \mathrm{O}\right.$ and $\left.\delta^{13} \mathrm{C}\right)$ of Lower-Middle Jurassic belemnites from the Western Balkan mountains (Bulgaria): Palaeoenvironmental application. Appl. Geochem. 23, 2845-2856.

Morten, S.D., Twitchet, R.J., 2009. Fluctuations in the body size of marine invertebrates through the Pliensbachian-Toarcian extinction event. Palaeogeogr. Palaeoclimatol. Palaeoecol. 284, 2938.

Nikitenko, B.L., 2008. The Early Jurassic to Aalenian paleobiogeography of the Arctic Realm: implications of microbenthos (foraminifers and ostracods). Stratigr. Geol. Correl. 1, 59-80.

Nikitenko, B.L., Shurygin, B.N., 1994. Lower Toarcian black shales and Pliensbachian-Toarcian crisis of the biota of Siberian Paleoseas. 1992 Proc. Int. Con. Arctic Margins, U.S. Dep.Int. min. Manag. Serv. Alaska Outer Cont. Shelf Region, Anchorage, USA, pp. 39-45.

Nocchi, M., Bartolini, A., 1994. Investigation on Late Domerian-Early Toarcian Lagenina an Glomospirella assemblages in the Umbria-Marche Basin (Central Italy). Geobios. Mém. Spéc. 17, 689-699.

Ogg, J.G., 2004. The Jurassic period. In: Gradstein, F.M., Ogg, J.G., Smith, A. (Eds.), A Geologic Time Scale 2004. Cambridge Univ. Press, pp. 307-343.

Osete, M.L., Villalaín, J.J., Osete, C., Gialanella, P.R., 2000. Evolución de Iberia durante el Jurásico a partir de datos paleomagnéticos. Geotemas 1, 117-119.

Osete, M.L., Gialanella, P.R., Gómez, J.J., Villalaín, J.J., Goy, A., Heller, F., 2007. Magnetostratigraphy of Early-Middle Toarcian expanded sections from the Iberian Range (central Spain). Earth. Planet. Sci. Lett. 259, 319-332.

Osete, M.L., Gómez, J.J., Pavón-Carrasco, F.J., Villalaín, J.J., Palencia, A., Ruiz-Martinez, V.C., Heller, F., 2011. The evolution of Iberia during the Jurassic from palaeomagnetic data. Tectonophysics 502, 55-65.

Pálfy, J., Smith, P.L., 2000. Synchrony between Early Jurassic extinction, oceanic anoxic event, and the Karoo-Ferrar flood basalt volcanism. Geology 28, 747-750.

Parisi, G., Ortega-Huertas, M., Nocchi, M., Palomo, I., Monaco, P., Martínez, F., 1996. Stratigraphy and geochemical anomalies of the early Toarcian oxygen-poor interval in the Umbria-Marche Apennines (Italy). Geobios 29, 469-484.

Pearce, C.R., Cohen, A.S., Coe, A.L., Burton, K.W., 2006. Changes in the extent of marine anoxia during the Early Jurassic: evidence from molybdenum isotopes. Gold- schmid Conference Abstractcs. doi:10.1016/j.gca.06.1415.

Perilli, N., 1996a. Calcareous nannofossils. In: Ureta, S. (Ed.), 1st Toarcian and 4th Aalenian Working Groups Meeting. Field Trip Iberian Range Guide-Book. Department of Paleontology Universidad Complutense de Madrid, pp. 20-22.

Perilli, N., 1996b. Calcareous nannofossils. In: Ureta, S. (Ed.), 1st Toarcian and 4th Aalenian Working Groups Meeting. Field Trip Iberian Range Guide-Book. Department of Paleontology Universidad Complutense de Madrid, pp. 44-47.

Perilli, N., 2000. Calibration of early-middle Toarcian nannofossil events based on high resolution ammonite biostratigraphy in two expanded sections from the Iberian Range (East Spain). Mar. Micropaleontol. 39, 293-308.

Perilli, N., Rodrigues, R., Veiga de Oliveira, L.C., Catanzariti, R., 2009. Lower Toarcian organicrich sediments from the Tuscan Succession (Northern Apennines, Italy): preliminary results. Volumina Jurassica 7, 55-65.

Philippe, M., Thevenard, F., 1996. Distribution and palaeoecology of the Mesozoic wood genus Xenoxylon: palaeoclimatological implications for the Jurassic of western Europe. Rev. Palaeobot. Palynol. 91, 353-370.

Price, G.D., 1999. The evidence of polar ice during the Mesozoic. Earth-Sci. Rev. 48, 183-210.

Price, G.D., Twitchett, R.J., Smale, C., Marks, V., 2009. Isotopic analysis of the life history of the enigmatic squid Spirula spirula, with implications for studies of fossil cephalopods. Palaios 24, 273-279.

Quesada, S., Robles, S., Rosales, I., 2005. Depositional architecture and transgressive- regressive cycles within Liassic backstepping carbonate ramps in the Basque- Cantabrian Basin, northern Spain. J. Geol. Soc. London 162, 531-548.

Rexfort, A., Mutterlose, J., 2009. The role of biogeography and ecology on the isotope signature of cuttlefishes (Cephalopoda,Sepiidae) and the impact on belemnite studies. Palaeogeogr. Palaeoclimatol. Palaeoecol 244, 212-221.

Rodríguez-Tovar, F.J., Uchman, A., 2010. Ichnofabric evidence for the lack of bottom anoxi during the Lower Toarcian oceanic anoxic event in the Fuente de la Vidriera section, Betic Cordillera, Spain. Palaios 25, 576-587.
Rogov, M.A., Zakharov, V.A., 2010. Jurassic and Lower Cretaceous glendonite occurrences and their implication for Arctic paleoclimate reconstructions and stratigraphy. Earth Sci. Frontiers. Spec. Issue. 17, 345-347.

Röhl, H.J., Schmid-Röhl, A., Oschmann, W., Frimmel, A., Schwark, L., 2001. The Posidonia Shale (Lower Toarcian) of SW-Germany: an oxygen-depleted ecosystem controlled by sea level and palaeoclimate. Palaeogeogr. Palaeoclimatol. Palaeoecol. 165, 27-52.

Rosales, I., Quesada, S., Robles, S., 2004. Paleotemperature variations of Early Jurassic seawater recorded in geochemical trends of belemnites from the Basque-Cantabrian basin, northern Spain. Palaeogeogr. Palaeoclimatol. Palaeoecol. 203, 253-275.

Ruban, D.A., Tyszka, J., 2005. Diversity dynamics and mass extinction of the Early- Middle Jurassic foraminifers: a record from the Northwestern Caucasus. Palaeo- geogr. Palaeoclimatol. Palaeoecol. 222, 329-343.

Sabatino, N., Neri, R., Bellanca, A., Jenkyns, H., Baudin, F., Parisi, G., Masetti, D., 2009. Carbon- isotope records of the Early Jurasic (Toarcian) oceanic anoxic event from the Valdorbia (Umbria-Marche Apennines) and Monte Mangart (Julian Alps) sections: palaeocea- nographic and stratigraphic implications. Sedimentology 56, 1307-1328.

Sackleton, N.J., Kennet, J.P., 1975. Paleotemperature history of the Cenozoic and the initiation of Antartic glaciation: oxygen and carbon isotope analysis in DSDP sites 277, 279 and 281. In: Kennet, J.P., Houtz, R.E., et al. (Eds.), Initial Reports of the Deep Sea Drilling Projects, 29. Government Printing Office, Washington: U. S., pp. 743-756.

Sælen, G., Doyle, P., Talbot, M.R., 1996. Stable-isotope analyses of belemnite rostra from the Whitby Mudstone Fm., England: surface water conditions during deposition of a marine black shale. Palaios 11, 97-117

Savrda, C.E., Bottjer, D.J., 1986. Trace-fossil model for reconstruction of paleo- oxygenation in bottom waters. Geology 14, 3-6.

Schmid-Röhl, A., Röhl, H.J., Oschmann, W., Frimmel, A., Schwark, L., 2002. Palaeoenvir- onmental reconstruction of Lower Toarcian epicontinental black shales (Posidonia Shale, SW Germany): global versus regional control. Geobios 35, 13-20.

Stampfli, G.M., Borel, G.D., 2002. A plate tectonic model for the Paleozoic and Mesozoic constrained by dynamic plate boundaries and restored synthetic ocean isochrones. Earth Planet. Sci. Lett. 196, 17-33.

Stampfli, G.M., Borel, G.D., 2004. The TRANSMED transects in space and time: constraints on the paleotectonic evolution of the Mediterranean domain. In: Cavazza, W., Roure, F.M., Spakman, W., Stampfli, G.M., Ziegler, P.A. (Eds.), The TRANSMED AtlasThe Mediterranean Region from Crust to Mantle. Springer, Berlin Heidelberg New York, pp. 53-80. and CD-ROM

Suan, G., Mattioli, E., Pittet, B., Maillot, S., Lécuyer, C., 2008. Evidence for major environmental perturbation prior to and during the Toarcian (Early Jurassic) Oceanic Anoxic Event from the Lusitanian Basin, Portugal. Paleoceanography 23, PA 1202. doi:10.1029/2007PA001459.

Suan, G., Mattioli, E., Pittet, B., Maillot, S., Lécuyer, C., Suchéras-Marx, B., Duarte, L.V., Philippe, M., Reggiani, L., Martineau, F., 2010. Secular environmental precursors to Early Toarcian (Jurassic) extreme climate changes. Earth. Planet. Sci. Lett. 290, 448-458.

Suárez-Vega, L.C., 1974. Estratigrafía del Jurásico en Asturias. Cuad. Geol. Ibérica 3, 1-369.

Tremolada, F., van de Schootbrugge, B., Erba, E., 2005. Early Jurassic schizosphaerellid crisis in Cantabria, Spain: implications for calcification rates and phytoplankton evolution across the Toarcian oceanic anoxic event. Paleoceanography 20, PA211. doi:10.1029/2004PA001120.

Twitchett, R.J., 2006. The palaeoclimatology, palaeoecology and palaeoenvironmental analysis of mass extinction events. Palaeogeogr. Palaeoclimatol. Palaeoecol. 232, 190-213.

Valenzuela, M., 1988. Estratigrafía, sedimentología y paleogeografía del Jurásico de Asturias. Ph D. Thesis, Depto. Geología Univ. Oviedo, Spain.

van de Schootbrugge, B., Bailey, T.R., Rosenthal, Y., Katz, M.E., Wright, J.D., Feist-Burkhardt, S., Miller, K.G., Falkowski, P.G., 2005a. Early Jurassic climate change and the radiation of organic-walled phytoplankton in the Tethys ocean. Paleobiology 31, 73-97.

van de Schootbrugge, B., McArthur, J.M., Bailey, T.R., Rosenthal, Y., Wright, J.D., Miller, K.G., 2005b. Toarcian oceanic anoxic event: an assessment of global causes using belemnite C isotope records. Paleoceanography 20, PA3008. doi:10.1029/ 2004PA001102.

Vera, J.A., 2001. Evolution of the south Iberian continental margin. In: Ziegler, P.A., Cavazza, W., Robertson, A.H.F., Crasquin-Soleau, S. (Eds.), Pery-Tethys Memoir 6: Peri-Thetyan Rift/Wrench Basins and Passive Margins: Mém. Mus. Natl. Hist. Nat., 186, pp. 109-143.

Vörös, A., 2002. Victims of the Early Toarcian anoxic event: the radiation and extinction of Jurassic Koninckinidae (Brachiopoda). Lethaia 35, 345-357.

Walther, G.R., Post, E., Convey, P., Menzels, A., Parmesan, C., Beebee, T.J.C., Fromentin, J.M., 2002. Ecological response to recent climate change. Nature 416, 389-395.

Wignall, P.B., Newton, R.J., Little, C.T.S., 2005. The timing of paleoenvironmental change and causeand-effect relationships during the early Jurassic mass extinction in Europe. Am. J. Sci. 305, 1014-1032.

Wignall, P.B., McArthur, J.M., Little, C.T., Hallam, A., 2006. Methane release in the Early Jurassic period. Nature 441, E5 (Comments to Kemp et al., 2005).

Wright, E.K., 1987. Stratification and paleocirculation of the Late Cretaceous Western Interior Seaway of North America. Geol. Soc. Am. Bull. 99, 480-490.

Xia, M., Xiao, S., Chen, L., Haisheng, Y., 2010. Black shales, isotope, organic geochemistry and the Early Toarcian oceanic anoxic event (OAE) in Northern Tibet. Earth Sci. Frontiers, Spec. Publ. 17, 362-363.

Zakharov, V.A., Shurygin, B.N., Il'ina, V.I., Nikitenko, B.L., 2006. Pliensbachian-Toarcian biotic turnover in North Siberia and the Arctic Region. Stratigr. Geol. Correl. 14, 399-417.

Ziegler, P.A., 1990. Geological Atlas of Western and Central Europe. Shell International Petroleum. Maatschappi B.V. Geological Society Publishing House, Bath, pp. 1-239. 